\title{
Larval size-distributions of Ariosoma balearicum cryptic species during the March-April season in the Sargasso Sea Subtropical Convergence Zone
}

\author{
Miller Michael J. 1, 2, ${ }^{*}$, Marohn Lasse ${ }^{3}$, Wysujack Klaus ${ }^{3}$, Bonhommeau Sylvain ${ }^{4}$, Kuroki Mari ${ }^{2}$, \\ Freese Marko ${ }^{3}$, Pohlmann Jan-Dag ${ }^{3}$, Watanabe Shun ${ }^{5}$, Blancke Tina ${ }^{3}$, Weist Peggy ${ }^{3}$, \\ Castonguay Martin ${ }^{6}$, Westerberg Håkan ${ }^{7}$, Tsukamoto Katsumi ${ }^{1,2}$, Hanel Reinhold ${ }^{3}$
}

1 Department of Marine Science and Resources, College of Bioresource SciencesNihon

UniversityFujisawa, Japan

${ }^{2}$ Department of Aquatic Bioscience, Graduate School of Agricultural and Life SciencesThe University of TokyoTokyo, Japan

3 Thünen Institute of Fisheries EcologyBremerhaven, Germany

4 IfremerLe Port Cedex, France

${ }^{5}$ Department of Fisheries, Faculty of AgricultureKindai UniversityNara, Japan

${ }^{6}$ Fisheries and Oceans Canadalnstitut Maurice-LamontagneMont-Joli, Canada

7 Department of Aquatic Resources, Institute of Freshwater ResearchSwedish University of Agricultural SciencesDrottningholm, Sweden

* Corresponding author : Michael J. Miller, email address : michael.miller@marine.fs.a.u-tokyo.ac.jp

\begin{abstract}
:
Leptocephali of the shallow-water congrid eel Ariosoma balearicum are abundant during February-April in the Sargasso Sea, and larval and adult meristic data indicates this species includes several regional subpopulations/cryptic species. Four multiple-transect larval surveys $(2011,2014,2015,2017)$ were used to examine the geographic size distribution of two myomere-count types of A. balearicum leptocephali. High-count (HC) larvae were consistently mostly between 80 and $100 \mathrm{~mm}$ in size $(60-132 \mathrm{~mm}$; $87.9 \pm 6.8 \mathrm{~mm}$ ) as observed previously, and frequently had narrow size ranges. The usually larger LC larvae $(78-176 \mathrm{~mm} ; 111.4 \pm 26.7 \mathrm{~mm})$ were more abundant in western or central areas. $\mathrm{HC}$ larvae tended to decrease in size from west to east and increase from south to north. Catch rates were geographically variable relative to hydrographic structure/frontal positions across the wide 2015 sampling area. Mitochondrial $16 \mathrm{~s}$ rRNA sequences of $\mathrm{HC}$ and LC larvae show species-level differences, providing evidence of the existence of two cryptic species with different larval dispersal strategies in the Sargasso Sea subtropical gyre region. The HC larvae disperse widely into the gyre, seemingly through Gulf Stream recirculation or eastward frontal-jet flows, and apparently must use directional swimming to cross the Florida Current to recruit into the South Atlantic Bight. LC leptocephali may mostly be retained near the Bahamas, with few larvae dispersing into the gyre. This seems to indicate natural selection occurred for spawning location and larval behavior due to the powerful Florida Current/Gulf Stream, resulting in two completely different spawning and larval dispersal strategies within a local geographic region.
\end{abstract}


Keywords: Ariosoma balearicum, Leptocephali, Larval dispersal, Sargasso Sea, Subtropical gyre, Cryptic species 


\section{Introduction}

The bandtooth conger eel, Ariosoma balearicum, is likely one of the most widely distributed and abundant congrid eels in the western North Atlantic (WNA). These small $(<340 \mathrm{~mm})$ marine eels live from the northern coast of Brazil, through the Caribbean, Bahamas and Gulf of Mexico and up to the southern US East Coast and are usually found at depths of < $100 \mathrm{~m}$ (Smith 1989a). They also occur in the eastern Atlantic and Mediterranean (Smith 1989a; Anibaldi et al. 2016). Its leptocephali have been collected in many areas, but they are especially common in the Sargasso Sea in the WNA where they are among the most abundant species of leptocephali (Smith 1989b; Miller and McCleave 1994, 2007; Miller 2002). Their larvae can also be abundant in the Florida Current area (southern part of the Gulf Stream) along the western margin of the Sargasso Sea, with some larvae possibly originating from other areas such as the Gulf of Mexico (Miller 1995; Ross et al. 2007) where they are abundant relative to other species (Smith 1989b, Crabtree et al. 1992; Quattrini et al. 2019).

Smith (1989a,b) found that this species likely consists of several subpopulations throughout its range because counts of the number of vertebrae in adults and of myomeres (muscle segments) in larvae differed among areas. Additional analysis of more than 4500 A. balearicum larvae from the WNA from 17 research cruises supported his conclusions that there were both high myomere (HC; $\geq 128$ myomeres) and low myomere (LC; $\leq 127$ myomeres) count larvae that must be from different populations (Miller 2002). Smith (1989a) found HC eels along the South Atlantic Bight (SAB) of the southern US east coast using vertebral counts of some eels, whereas the LC eels were found in the Bahamas, Gulf of Mexico and Caribbean, yet their larvae overlap in the Sargasso Sea. Collections of LC leptocephali in the Gulf of Mexico suggest spawning occurred over or near the continental slope (Quattrini et al. 2019), and HC and LC larvae have been collected within or along the western edge of the Florida Current along the SAB (Miller 1995, 2002; Ross et al. 2007). Another area where HC eels were detected was off the northeast coast of South America (Guiana, Brazil; Smith 1989a) and larvae in that area also had HC myomere counts (Miller 2002).

A 7-cruise larval sampling campaign to study American eel, Anguilla rostrata, leptocephali during 5 different years in the Sargasso Sea between 1981 and 1989 (McCleave and Kleckner 1987; Kleckner and McCleave 1988; Miller and McCleave 1994) provided valuable data about A. balearicum leptocephali in various areas or times of year (Miller 2002; Miller and McCleave 2007). The sampling surveys in the spring season found that $A$. balearicum larvae were often the second or third most abundant species in the STCZ among all types of anguilliform leptocephali, with mesopelagic nemichthyid eel larvae being most abundant, and anguillid and serrivomerid larvae whose adults that also spawn offshore also being abundant (Miller and McCleave 1994). Mesopelagic eels and anguillid eels spawn offshore based on the presence of their small leptocephali (Miller and McCleave 1994), but no small A. balearicum 
were collected offshore in the Sargasso Sea. Although, some small LC and HC larvae have been collected along the western side of the Florida Current (Ross et al. 2007), extensive ichthyoplankton surveys across the $\mathrm{SAB}$ or in specific areas there have reported no evidence of $A$. balearicum larvae from spawning in that region (e.g., Fahay 1975; Powles and Stender 1976; Powell and Robbins 1994, 1998; Marancik et al. 2005; Quattrini et al. 2005). In contrast, the larvae of the Ophichthidae are typically reported there as analyzed by Fahay and Obenchain (1978). However, large numbers of small LC larvae were collected within the Northwest Providence Channel of the Northern Bahamas, and examinations of A. balearicum larvae from other types of collections in the Gulf Stream region north of Bermuda revealed the presence of smaller HC larvae (Miller 2002). The data from the American eel surveys and Gulf Stream system indicated that metamorphosing larvae were mostly found within the Florida Current (Miller 1995, 2002).

The distributions and sizes of the two types of leptocephali in the Sargasso Sea region led to the hypothesis that the $\mathrm{HC}$ eels migrate from the $\mathrm{SAB}$ to spawn somewhere along the eastern edge of the Florida Current (Miller 2002). Their larvae would then become widely distributed in the Sargasso Sea subtropical gyre before moving west and swimming across the Florida Current to reach the SAB. While this seems like an improbable life history, both the leptocephali of the American eel (Schoth and Tesch 1982; Kleckner and McCleave 1988; Miller et al. 2015) and the American conger, Conger oceanicus (McCleave and Miller 1994; Miller et al. 2011) are spawned offshore in the southwestern Sargasso Sea, and their larvae also must seemingly actively swim to cross the Florida Current and Gulf Stream to reach their recruitment areas along the east coast of North America (Miller and Tsukamoto 2017). Fahay (2007) also describes this life history scenario for the HC A. balearicum eels in the SAB and the HC leptocephali in the Sargasso Sea.

Although the large A. balearicum leptocephali are widely distributed in the Sargasso Sea during the winter and spring seasons (Miller and McCleave 1994; Miller 2002), the American eel leptocephali originate from offshore spawning in the warmer southern water mass south of temperature fronts that form in the Sargasso Sea Subtropical Convergence Zone (STCZ) before they spread out more widely in the gyre (Kleckner and McCleave 1985, 1988; Munk et al. 2010; Miller et al. 2015). Remarkably, the same size range of mostly 80-100 mm HC A. balearicum leptocephali was present across the STCZ and near Bermuda every sampling year during February to March (Miller 2002; Hanel et al. 2014). Their leptocephali are smaller during the fall, so spawning may mostly occur during summer (Miller 2002; Miller and McCleave 2007).

The spatial aspects of how A. balearicum leptocephali are distributed across the STCZ were not examined in previous studies, which is important for understanding spawning locations and larval dispersal because of the complex circulation and hydrography of the area. The fronts that form there have associated eastward flowing frontal jets (Eriksen et al. 1991; Pollard and Regier 1992), which likely transport some leptocephali eastward, based on the offshore presence of species of leptocephali that do not spawn there (Miller and McCleave 1994). There is also westward or southward Gulf Stream recirculation in the northern Sargasso Sea and probably some larger-scale subtropical gyre recirculation (McWilliams 1983; Marchese 1999) that could transport leptocephali within the gyre. If the HC eels spawn along the eastern side of the Florida Current and LC eels spawn within the Northern Bahamas as hypothesized (Miller 2002), then some combination of the ocean circulation features of the Sargasso Sea must account for how the leptocephali are transported offshore into the Sargasso Sea. In addition, the $\mathrm{HC}$ and LC forms have not been tested genetically to verify the hypothesis that they are different populations or cryptic species.

The present study examines the distribution and size of $A$. balearicum leptocephali in latitudinal and longitudinal axes during 4 sampling surveys with multiple transects to collect leptocephali in extensive grids of stations across the STCZ to evaluate the dispersal ecology of the two forms of larvae. We also provide the first genetic comparison of mtDNA sequences of the HC and LC leptocephali that indicates they are likely separate cryptic species. The findings of the study are compared to existing information to evaluate their implications for the different life histories and larval dispersal strategies of these two cryptic species of A. balearicum whose larvae are present in the Sargasso Sea.

\section{Methods and Materials}

Sampling for leptocephali was conducted during 4 research cruises made by two different German research vessels during March and April of 4 different years (Table 1). Three cruises were conducted by the German Thünen Institute of Fisheries Ecology onboard the R/V Walther Herwig III (WH; 2011, 2014, 2017) and an interdisciplinary survey was conducted onboard the R/V Maria S. Merian (MSM; 2015) (Fig. 1). The primary objective of the WH surveys was to document the abundance and distribution of European eel, Anguilla anguilla, leptocephali during their spawning season at 3-year intervals (Hanel et 
al. 2014). With spawning occurring south of the northern front (Kleckner and McCleave 1988; Munk et al. 2010) across a wide range of longitude (Schoth and Tesch 1982; Miller et al. 2019), the sampling efforts of the WH surveys were designed to cross the northern and southern fronts in most transects to ensure that tightly spaced stations ( 0.5 degrees of latitude) were distributed across the zones latitude and longitude where anguillid larvae should be present. The northern front was not always crossed if meanders extended to the north in some locations, but many of the same transect locations were sampled each year (Fig. 1,2). The number of transects in the $2017 \mathrm{WH}$ survey was reduced because of rough seas and a shorter cruise duration. The 2015 MSM survey was designed to cross a much wider latitudinal zone with more widely spaced stations in most areas to study the ecology of the European eel spawning area region. Other taxonomic groups of organisms such as zooplankton and cephalopods (Lischka et al. 2017) were also studied using various gears (see below), and this wide geographic survey was used to examine the regional catch rates of A. balearicum leptocephali.
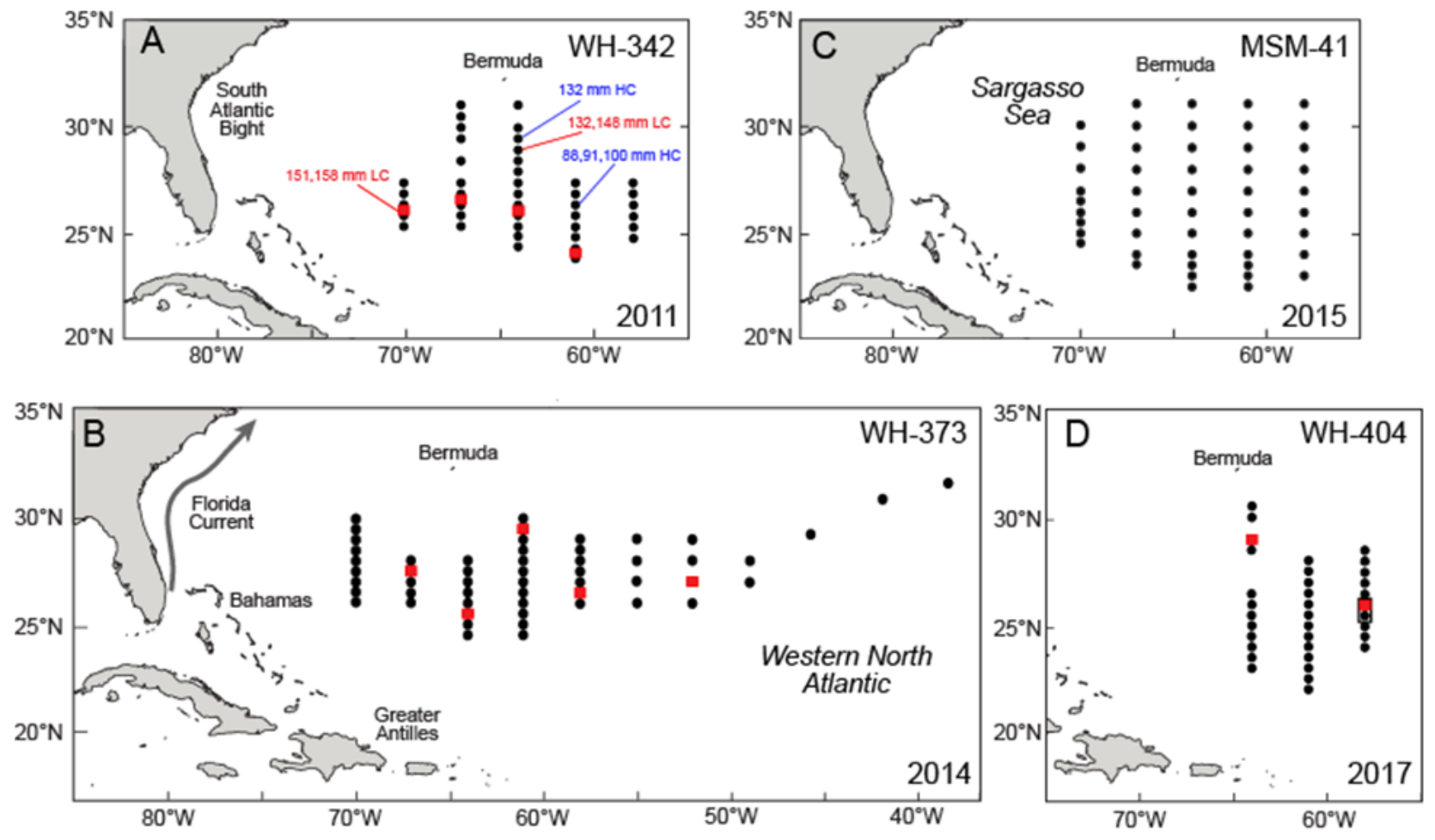

Fig. 1. Maps of the primary sampling stations for collecting leptocephali in the Sargasso Sea from 2011 to 2017 during the R/V Walther Herwig III (WH-342, WH-373, WH-404) and the R/V Maria S. Marian (MSM-41) surveys that primarily used an Isaccs-Kidd Midwater Trawl (IKMT). Red squares show locations where a large pelagic trawl was used in addition to the IKMT. Some intermediate locations or stations that included multiple tows that are not shown except the area shown with a rectangle in 2017. The collection locations and sizes of the 8 larvae used for genetic analysis in 2011 are shown in (A).

During all 4 surveys, a $6.2 \mathrm{~m}^{2}$ mouth-opening, flow meter equipped, Isaacs-Kidd Midwater Trawl (IKMT; Hydro-Bios Apparatebau $\mathrm{GmbH}$ ) with $0.5 \mathrm{~mm}$ mesh was used to collect leptocephali in standardized double-oblique tows fished to $300 \mathrm{~m}$ depths during both day or night with a speed through the water of $2.5 \mathrm{kn}$ (see Miller et al. 2013, Hanel et al. 2014). One of these "standard IKMT tows" was made at each station following the deployment methodology of Kleckner and McCleave (1988) for intercomparison with those earlier surveys $(1983,1985)$, but other types of IKMT deployments or gear types were also used.

The standard IKMT tows were used to examine the geographic distribution of A. balearicum abundance in the most geographically widespread sampling in 2015 and the spatial distribution of size during all 4 surveys. Individual-station catch rates of A. balearicum leptocephali were calculated (as the number of larvae per $10^{5} \mathrm{~m}^{3}$ of water filtered) using the larvae collected by the standardized doubleoblique tows of the IKMT. Several factors likely contribute to variability in catches of leptocephali in the STCZ, such as time of day, and current flow and tow volume differences among stations, so except for the 2015 survey, catch rates will not be a focus of the present study. 
Table 1. Numbers and total lengths (TL) of Ariosoma balearicum leptocephali collected during 4 sampling surveys in the Sargasso Sea using an IKMT and other types of gear during March and April of each year including information about the larvae designated as being the high (HC) and low (LC) form or as being pre-metamorphosing (pre-meta) or metamorphosing (meta) larvae.

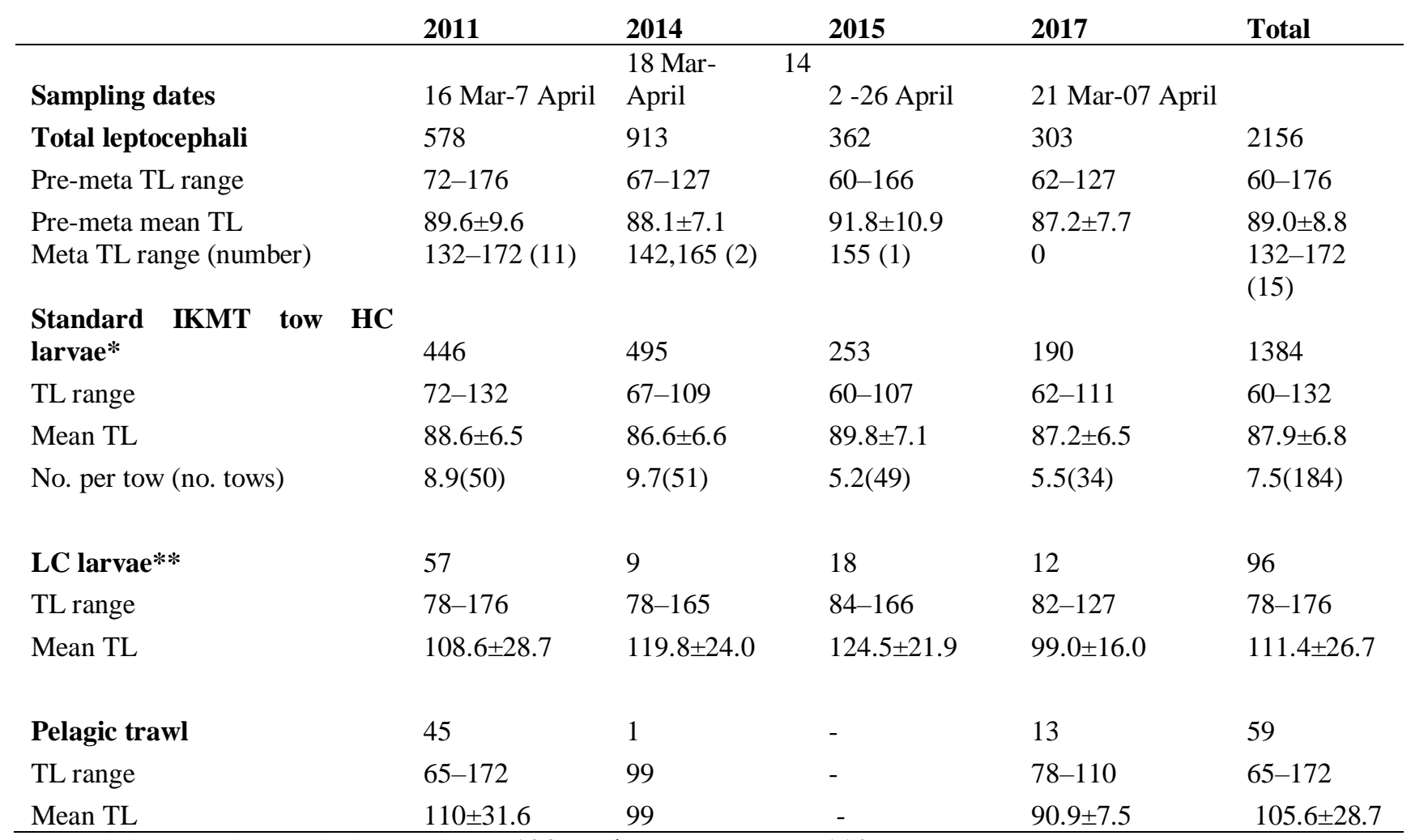

$*$ High count larvae designated as $\geq 128$ total myomeres or $<110 \mathrm{~mm}$.

$* *$ Low count larvae designated as $\leq 127$ total myomeres or $\geq 110 \mathrm{~mm}$.

A large pelagic fisheries trawl (Engel-Netze GmbH and Co. KG) was used during 2011 (4 deployments), 2014 (7), and 2017 (3) (Fig. 1) that had a $30 \mathrm{~m}$ width , $20 \mathrm{~m}$ height , $145 \mathrm{~m}$ length (mesh sizes from $90 \mathrm{~cm}$ grading down to 40,20,10,5,4,3,2 cm, with $1.5-\mathrm{cm}$ mesh in the $27-\mathrm{m}$ long cod end) as overviewed previously (Miller et al. 2013). In 2014 and 2017 the trawl had a multiple codend system. The trawl was deployed to target spawning anguillid eels (2011) and in most cases to sample the mesopelagic fauna at deeper depths, so except in 2011, the trawl was usually fished too deep to collect many leptocephali, which are mostly in the upper $100 \mathrm{~m}$ at night (Castonguay and McCleave 1987).

In 2014 and 2017 some horizontally towed IKMT deployments were made to sample specific depth layers in the upper $100 \mathrm{~m}$ at night, but the details are not relevant for the present study, and these tows were excluded from statistical/regression analyses of larval size among surveys. One horizontal tow affected the overall number collected during the 2014 survey (see results), because many A. balearicum were collected, likely because various taxa of leptocephali can sometimes be more abundant at specific depths at night (Castonguay and McCleave 1987; Miller 2009, 2015; Onda et al. 2017).

In 2015 other types of nets were deployed for catching plankton or micronekton that included a $13.5 \mathrm{~m}^{2}$ mouth opening IKMT (mesh size $5 \mathrm{~mm}$ ) fished down to $1000 \mathrm{~m}$ (10 deployments), a Multiple Opening Closing Net with Environmental Sensing System (MOCNESS, mesh sizes: $330 \mu \mathrm{m}$ and $2 \mathrm{~mm}$, mouth opening: $1 \mathrm{~m}^{2} ; 23$ deployments) (see Wiebe et al. 1985), a Multinet Vertical Plankton Sampler (MultiNet Midi, mesh size: $200 \mu \mathrm{m}$, mouth opening: $0.25 \mathrm{~m}^{2}$, Hydro-Bios Apparatebau GmbH; 21 deployments, no A. balearicum leptocephali collected), and a Manta Net (mesh size: $330 \mu \mathrm{m}$, mouth opening: $0.14 \mathrm{~m}^{2} ; 33$ deployments) for sampling the neuston layer. 


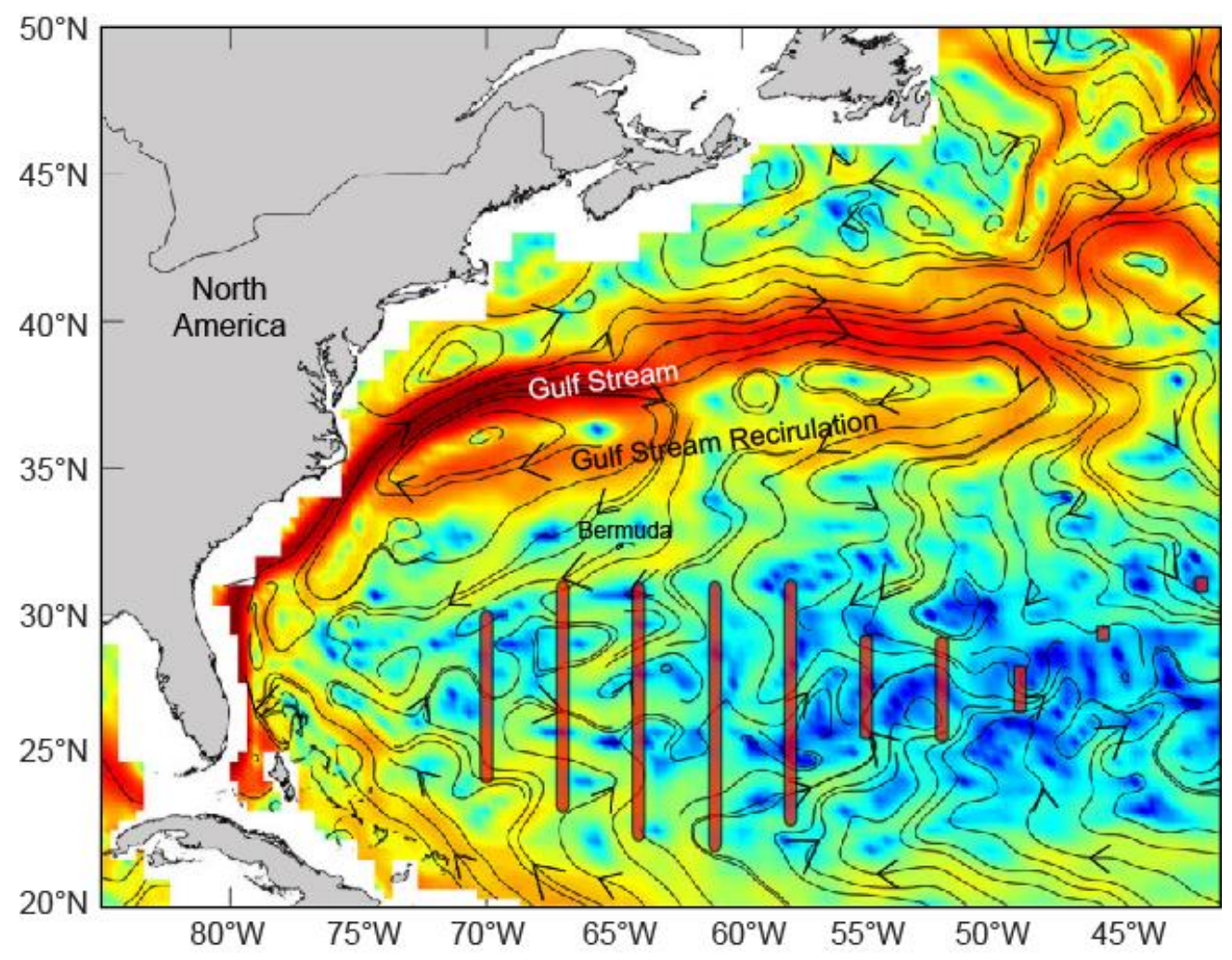

Fig. 2. Map of the Sargasso Sea and Gulf Stream region of the western North Atlantic showing the average surface current flow patterns that include Gulf Stream gyre recirculation that reaches into the southern Sargasso Sea and the areas where sampling took place during the 4 surveys of the present study (shaded ovals). The easternmost station where Ariosoma balearicum were collected in 2014 (Fig. 1) is not shown (outside the map area). The current flow image modified from Caldeira and Reis (2017) shows large-scale circulation calculated from an OSCAR-derived (Bonjean and Lagerloef 2002; Johnson et al. 2007) mean of sea surface currents (2004-2014) represented as isolines over $\log 10$ of the current velocity to emphasize the extremes.

Leptocephali were identified to be A. balearicum based on Smith (1989b) in comparison to other larvae (Böhlke 1989). Larvae were examined fresh after being sorted out of plankton samples and were measured to the nearest $1 \mathrm{~mm}$ total length (TL). Subsamples of a few undamaged larvae from most tows were randomly selected and counted for their total number of myomeres (TM) to determine if they were LC or HC larvae, but most large larvae were counted because they were likely to be LC larvae (Miller 2002). Myomere counts in the present study were made by 4 different people, compared to one person in the previous study (Miller 2002), but the same general pattern was seen. Myomere counts were made on $25 \%$ of the larvae collected.

Temperature, conductivity, depth (CTD) hydrographic casts were made at each station during all cruises to a depth of $500 \mathrm{~m}$ to analyze the hydrographic structure along each transect, but these data will not be the focus of the present study except for in 2015 (but see Hanel et al. 2014 for the 2011 and Westerberg et al. 2018 for the 2014 surveys). Frontal locations during each survey were determined from various online sea surface temperatures data sources during each cruise and were seen in hydrographic sections plotted from the CTD data.

Linear regression analyses were conducted to examine the relationship between the TL of HC larvae and latitude and longitude. Specimens $\geq 110 \mathrm{~mm}$ (most large larvae are LC; Miller 2002) were excluded unless they were HC based on myomere counts, and all LC larvae were excluded if they had counts of $\leq 127$ myomeres. Statistical comparisons were made using Kruskal-Wallis tests followed by pairwise Dunn's tests, or $U$-tests for 2-sample comparisons (significance criteria of $\mathrm{p}<0.05$ ).

Eight specimens of A. balearicum leptocephali (4 HC and 4 LC) from 4 stations (Fig. 1A) that were preserved in $99 \%$ ethanol during the 2011 survey were used for comparisons of their DNA sequences. They were selected based on their myomere counts and their size (wide size-range for $\mathrm{HC}$, and large size for LC). DNA-extraction was done using a small piece of the right eye that was incubated in 5\% ChelexSolution (Bio-Rad) with $240 \mu \mathrm{g}$ of Proteinase $\mathrm{K}$ for $3 \mathrm{~h}$ at $55^{\circ} \mathrm{C}$ and $25 \mathrm{~min}$. at $98^{\circ} \mathrm{C}$. PCR was conducted 
on mitochondrial 16s rRNA using Phusion ${ }^{\circledR}$ HighFidelity DNA Polymerase (New England Biolabs) and a universal primer pair listed as follows: 16L29, 5'-YGCCTGTTTATCAAAAACAT-3', and H3059, 5'CCGGTCTGAACTCAGATCACGT-3'. PCR products were purified by spin column-based purification (Qiagen PCR Purification Kit) and sequenced with Sanger sequencing method by LGC Genomics (Berlin, Germany). Consensus sequences were generated by pairwise alignment of forward and reverse sequences, resulting in a multiple sequence alignment with a length of $598 \mathrm{bp}$ (Online Resource 1). Mean pairwise genetic distances were then calculated among the HC and LC A. balearicum leptocephali and representative sequences of American eels ( 7 from our leptocephali collected in the Sargasso Sea; 3 from the NCBI GenBank: AJ244829.1, FJ603300.1, AP007249.2) and European eels (15 from our leptocephali; 3 from the NCBI GenBank: KJ564270.1, FJ603301.1, AJ244826.1). Analyses were conducted using the Kimura 2-parameter model (Kimura 1980). The analysis involved 36 nucleotide sequences, and there were 617 positions in the final dataset. Analyses were conducted in MEGA X (Kumar et al. 2018).

\section{Results}

Distribution, size and meristics of larvae

The 4 March-April sampling surveys conducted in overlapping areas of the Sargasso Sea from 20112017 collected a total of 2156 A. balearicum leptocephali (Table 1). The greatest number of larvae was collected in $2014(\mathrm{~N}=913)$ partly due to the 277 larvae caught in one IKMT deployment towed in 5 oblique movements up and down between depths of 90 and $150 \mathrm{~m}$ before sunrise (04:11-06:22) near the southern end of the westernmost transect $\left(26.5^{\circ} \mathrm{N} ; 70^{\circ} \mathrm{W}\right)$. From $303-533$ larvae were collected during the other 3 surveys.

A remarkably similar size of larvae was seen each year with most being between $80-100 \mathrm{~mm}$ (Fig. 3). The smallest larvae in each survey ranged from $60-72 \mathrm{~mm}(\mathrm{~N}=9$ total larvae $<70 \mathrm{~mm})$, and from 4-26 large larvae, $110-172 \mathrm{~mm}$, were collected during each survey ( $\mathrm{N}=55$ total). When apparent LC larvae ( $\geq 110 \mathrm{~mm}$ or $\leq 127$ myomeres) were excluded, the total lengths of the 1384 likely HC larvae collected in all the standardized IKMT tows were $60-132 \mathrm{~mm}$ with a mean of $87.9 \pm 6.8 \mathrm{~mm}$ (Table 1). The mean lengths of the HC leptocephali in the standard IKMT tows from each survey ranged from $86.6 \pm 6.6 \mathrm{~mm}$ in 2014 to $89.8 \pm 7.1 \mathrm{~mm}$ in 2015 , and their TL values were statistically different ( $\mathrm{p}<0.001$; Kruskal-Wallis) with 2015 being different than 2014 and 2017, and 2011 being different than 2014 (p < 0.05; Dunn's Test). The overall number of likely HC larvae (myomere counts of $\geq 128$, or $<110 \mathrm{~mm}$ with no myomere counts) collected per standard IKMT tow ranged from about 5-9 among the 4 surveys, with the highest catch being in 2014 (Table 1).
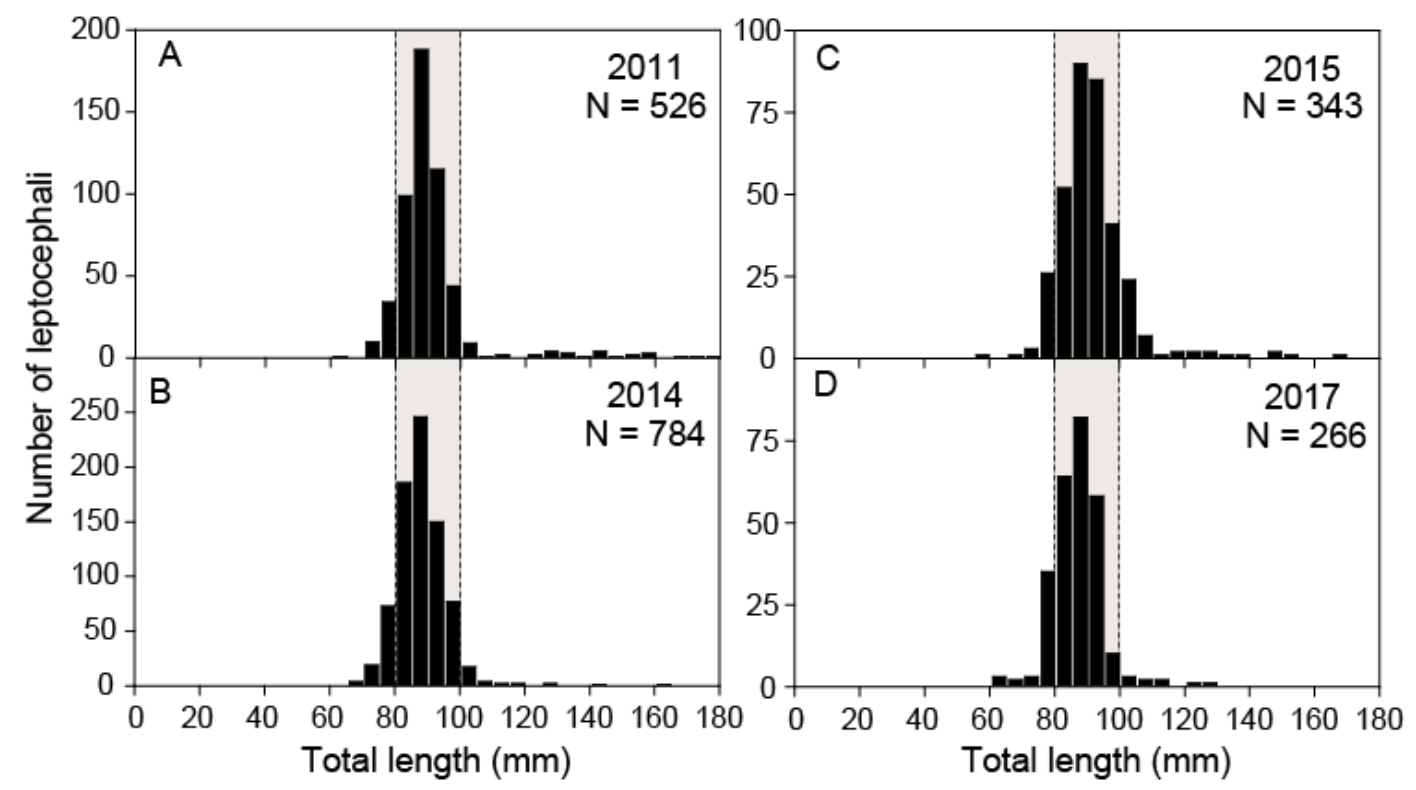

Fig. 3. Length-frequency distributions of the Ariosoma balearicum leptocephali (including HC and LC forms) collected by all types of gear during the 4 sampling surveys in the Sargasso Sea from 2011 to 2017. 
Myomere count subsamples of larvae during each survey indicated that the majority of larvae had counts in the $\mathrm{HC}$ range of $\geq 128 \mathrm{TM}$ for the main size class (Fig. 4). The TM counts of the HC leptocephali in the standard IKMT tows were not statistically different among years ( $p=0.53$; KruskalWallis), with mean TM only ranging from 131.0 to 131.5 myomeres. In 2011 when more counts were made there was a higher proportion of counts $\leq 127$ for larvae in the main size class. All but a few of the larger larvae had counts $\leq 127$ myomeres indicating they were the LC form. All except 2 (TM 128, 130) of the 14 metamorphosing larvae (132-172 mm) had LC myomere counts (TM 121-127), and 10 of those were collected in 3 pelagic trawl deployments in 2011 (see Miller et al. 2013), when shallow layers < 100 m were sampled.
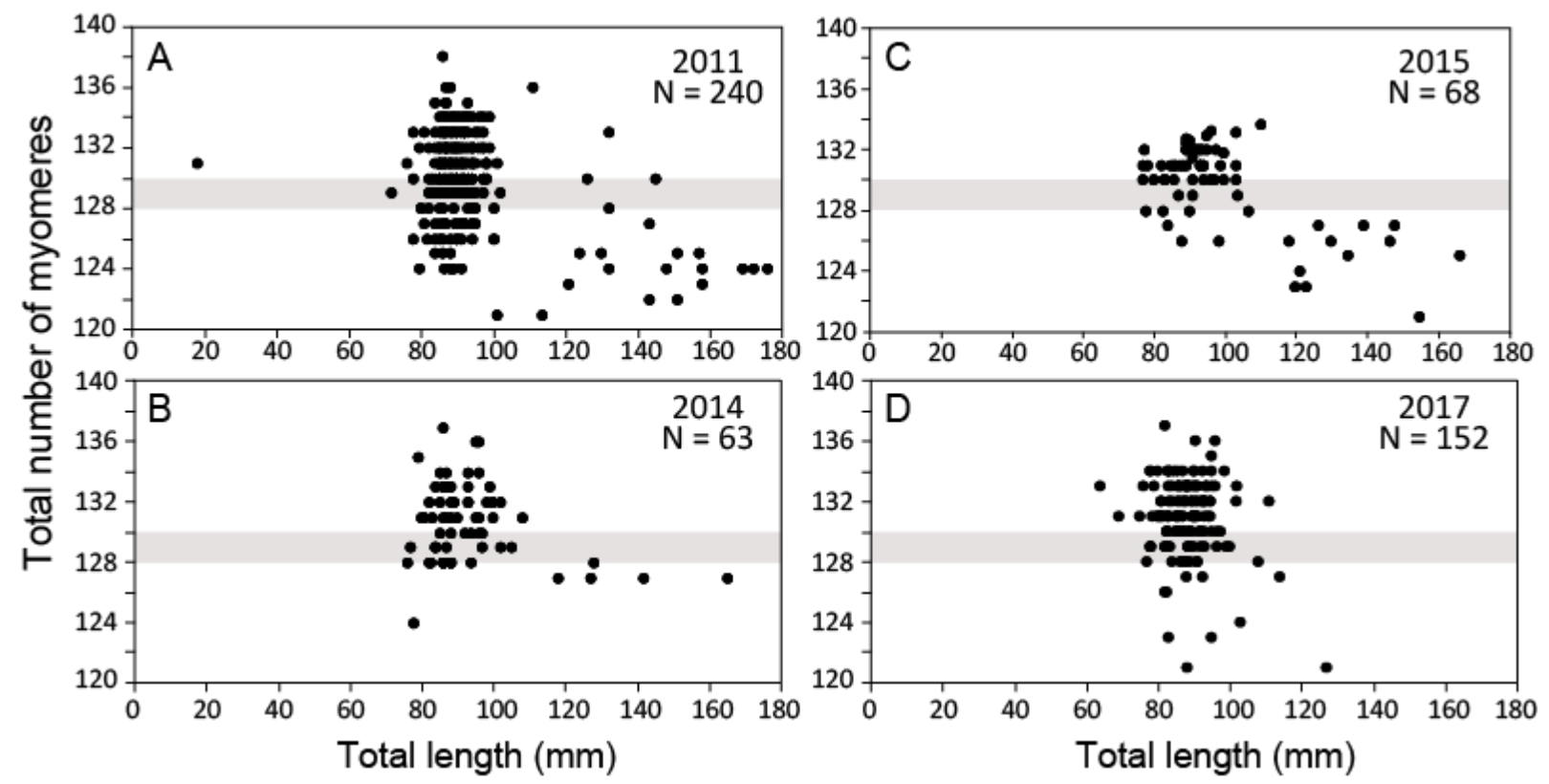

Fig. 4. Plots of the number of total myomeres (TM) versus total length of Ariosoma balearicum leptocephali collected during the 4 sampling surveys in the Sargasso Sea from 2011 to 2017. The highcount form appears to have $\geq 128$ myomeres and the low-count form has $\leq 127$ myomeres based on previous studies (Smith 1989a,b; Miller 2002). The shading shows the area of primary overlap in the TM counts between the two forms that was used by Miller (2002).

The distributions of larval size in relation to latitude and longitude during each survey showed that the main size class $(\sim 80-100 \mathrm{~mm})$ was widely distributed in all areas (Fig. 5). The presence of both the smaller and larger larvae varied within and among years, with few obvious trends. Narrow size ranges were seen at many stations including in the easternmost areas in 2011 and 2014. In 2014, larvae (77-96 $\mathrm{mm}$ ) were also collected at 3 individual stations (Fig. 1B) located to the northeast of the main study area ( $\mathrm{N}=8,5,1$ larvae from west to east), indicating A. balearicum leptocephali were present as far east as $38^{\circ} \mathrm{W}$. They were not caught at 4 stations located farther north and east on the cruise track that ended at the Azores Islands (not shown). The long north-south transects of more widely spaced stations in 2015 showed that there was more variability in sizes in the westernmost transect, but there were a few larger larvae in other transects (Fig. 6).

Regression analyses of the TL of likely HC larvae caught by the standardized IKMT catches from each survey in relation to latitude and longitude showed similar trends each year and for the overall combined data (Fig. 7). Decreasing TL trends from west to east and increasing trends from south to north were found with similar slopes of the linear regression lines. These linear relationships with TL were statistically significant ( $\mathrm{p}<0.05)$ for latitude in 2011, 2014, and 2015 and for longitude in 2014 and 2015. The plots showed that the sizes of HC larvae among transects had some similar patterns, such as smaller larvae at $61^{\circ} \mathrm{W}$ in some years, a narrow but larger size range at $31^{\circ} \mathrm{N}$, and smaller larvae at the central latitudes in 2014. Combining all data of the different surveys the overall TL of all the larvae (HC and LC) increased gradually with Julian date (day of year) at a rate of $0.18 \mathrm{~mm} /$ day over the 38-day period covered by the sampling, but this is not considered to be the growth rate of individual larvae. 

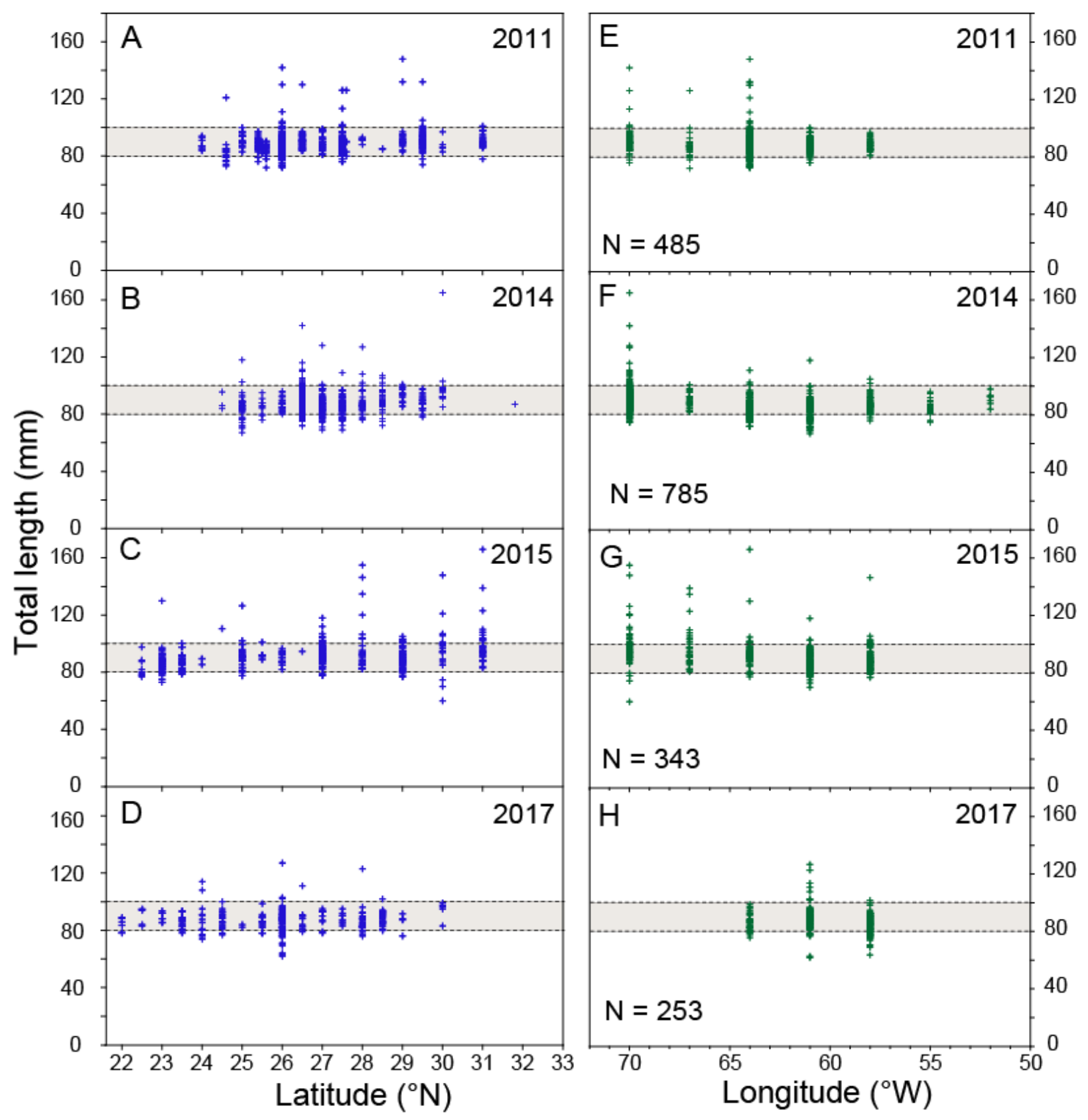

Fig. 5. Plots of the individual total lengths of the Ariosoma balearicum leptocephali (including HC and LC forms) collected by all types of gear except the large pelagic trawl during the 4 sampling surveys in the Sargasso Sea from 2011 to 2017 versus latitude and longitude of the stations. Larvae of the same sizes are overplotted and are not visible. The $80-100 \mathrm{~mm}$ size range is shaded to facilitate comparisons.

Distribution and catch rates in 2015 transects

The distribution of larvae and their catch rates at the 2015 stations showed larvae were widely present, but catches were not uniform across the sampling area (Fig. 8). Larvae were present in all areas (north and south sides) in relation to the fronts, including in the water mass north of the $22^{\circ} \mathrm{C}$ front and far south of the $24^{\circ} \mathrm{C}$ front (Fig. 8,9). Some stations located in many areas that were mostly sampled during the day had no catches except in the southwest and northeast (Fig. 8,9). This may not indicate they were absent however, since none were caught in the standard IKMT tow at the northernmost station in transect 2 at $67^{\circ} \mathrm{W}$ (St. 18), but several, including larger individuals were caught in the 5-mm mesh IKMT tow there (Fig. 6,8) (see below). The highest catch rates occurred far south of the southern $24^{\circ} \mathrm{C}$ front at the southern end of the eastern $61^{\circ} \mathrm{W}$ transect (Fig. 8,9C). Two of those stations had considerably higher catch rates than any other stations, except near the southern front along $64^{\circ} \mathrm{W}$ (Fig. 9). The catches of larvae along the 4 longest 2015 transects were variable spatially, with mean catch rates (number of larvae 
per $10^{5} \mathrm{~m}^{3}$ of water filtered) in each transect ranging from $16.0 \pm 23.9$ (Transect 4 ) to $5.7 \pm 7.0$ (Transect 2). The catch rates were not significantly different among the 5 transects (Kruskal-Wallis test, $p=0.53$ ), but there were only 9-12 stations per transect. Catch rates were higher and statistically different in night tows $(14.7 \pm 1.7$, mean \pm S.D., $\mathrm{N}=22$ stations $)$ than those during daytime $(5.4 \pm 7.9 ; \mathrm{N}=22)(U$-test, $\mathrm{p}$ $=0.35$ ). Catch rates of tows made during crepuscular periods (including both night and day fishing times) were intermediate $(9.4 \pm 5.1 ; \mathrm{N}=4)$, and 7 of the 10 IKMT tows that did not collect any A. balearicum larvae were day tows. The mean sizes in each transect that ranged from $92.0 \pm 11.4 \mathrm{~mm}$ (Transect 1) to $98.0 \pm 14.9 \mathrm{~mm}$ (Transect 2) were statistically different ( $\mathrm{p}<0.001$; ANOVA) with Transect $4(93.9 \pm$ $11.8 \mathrm{~mm})$ being different than transects 1 and $3(96.9 \pm 13.6 \mathrm{~mm})(\mathrm{p}<0.05$; Tukey Test $)$.
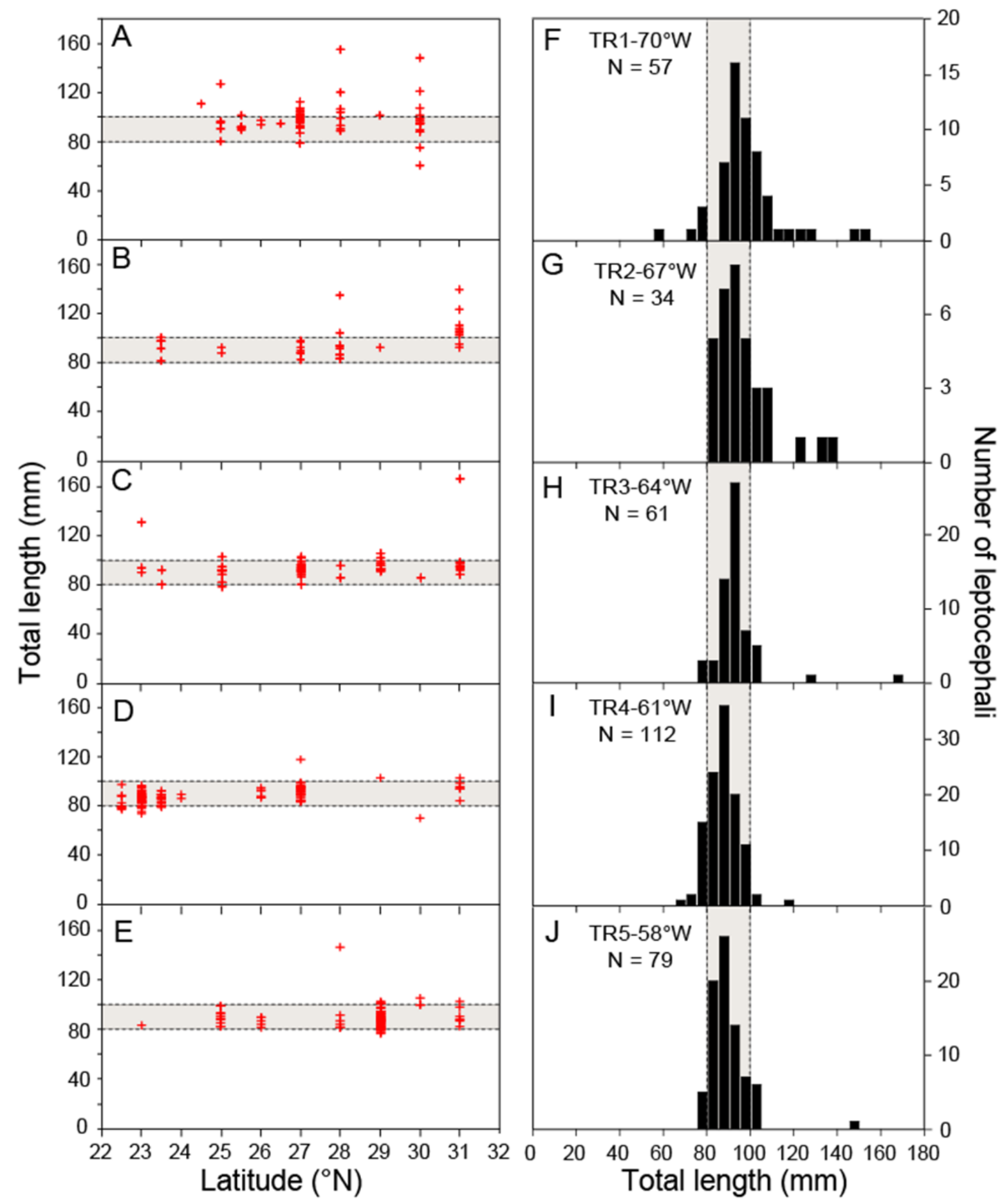

Fig. 6. Plots of the individual total lengths of the Ariosoma balearicum leptocephali (including HC and LC forms) collected by all types of gear in each transect (TR1-TR5) during the 2015 sampling survey versus latitude and longitude of the stations (left panels), and the length-frequency distributions of all the larvae caught in each transect (right panels). The $80-100 \mathrm{~mm}$ size range is shaded to facilitate comparisons. 

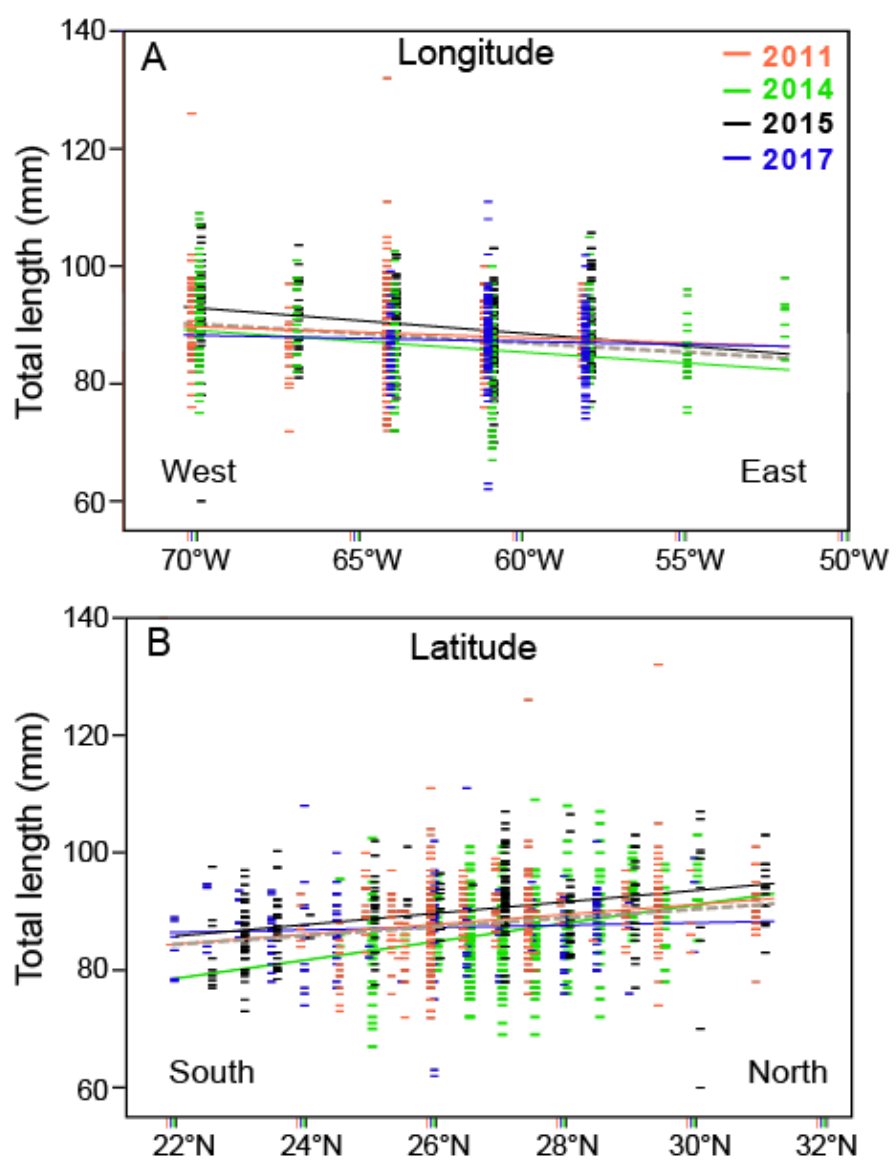

Fig. 7. Plots and linear regressions of the individual total lengths of the Ariosoma balearicum leptocephali (excluding those estimated to be LC individuals) collected in the standardized IKMT tows during each survey versus longitude (A) and latitude (B) of the stations, with the symbols for each survey being slightly offset laterally for visibility as reflected by the $\mathrm{x}$-axis markers. The dashed grey regression lines in each panel are for all data analyzed together.

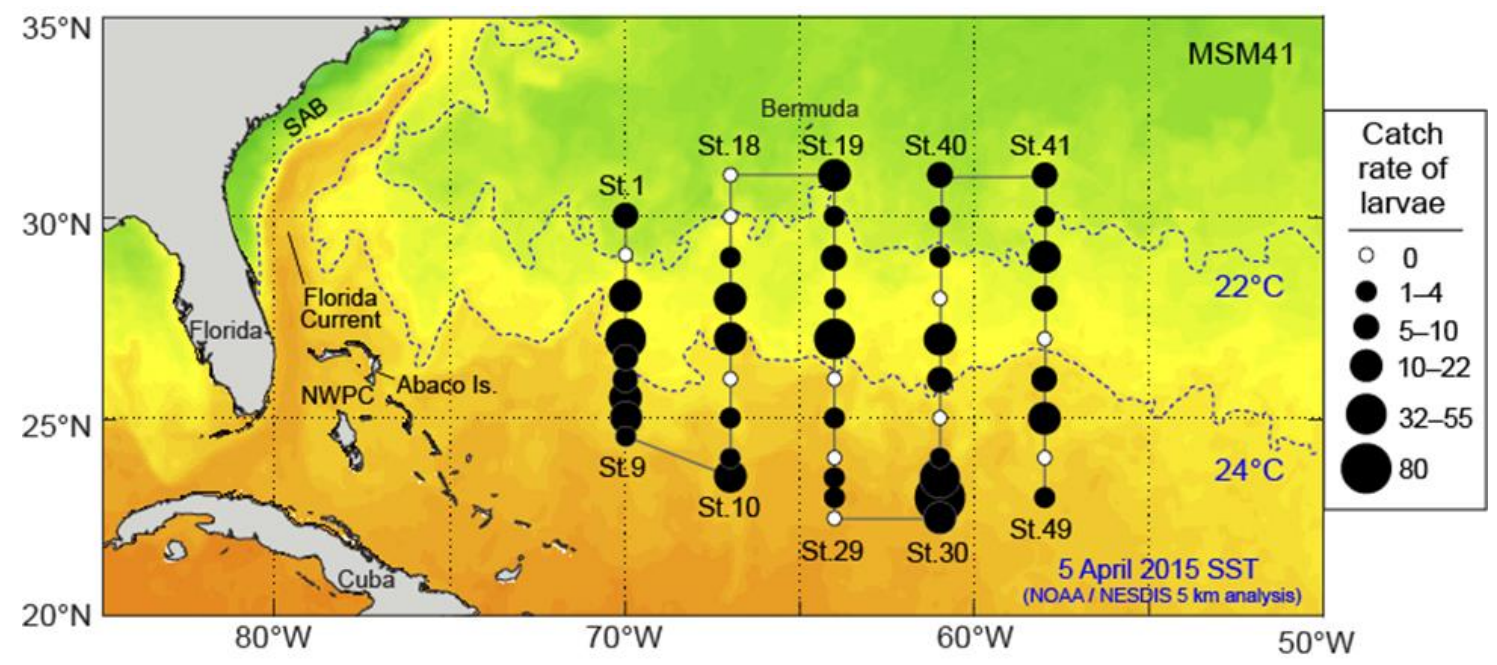

Fig. 8. Individual-station catch rates (number of larvae per $10^{5} \mathrm{~m}^{3}$ of water filtered) of the Ariosoma balearicum leptocephali (including HC and LC forms) collected in the standardized IKMT tows in each transect (west, TR1-TR5, east) during the 2015 sampling survey. The surface expression of the two fronts associated with the $22^{\circ} \mathrm{C}$ (north) and $24^{\circ} \mathrm{C}$ (south) isotherms are shown with dashed lines based on a sea surface temperature image from 5 April 2015. The exact location of where the fronts were crossed during each transect varied over time due to their dynamic nature, so they could be slightly different in location compared to in the hydrographic sections in Figure 9 that are based on CTD data from the survey. The Northwest Providence Channel (NWPC) and Abaco Island of the Northern Bahamas and the South Atlantic Bight (SAB) where $\mathrm{HC}$ eels have been found are labeled. 

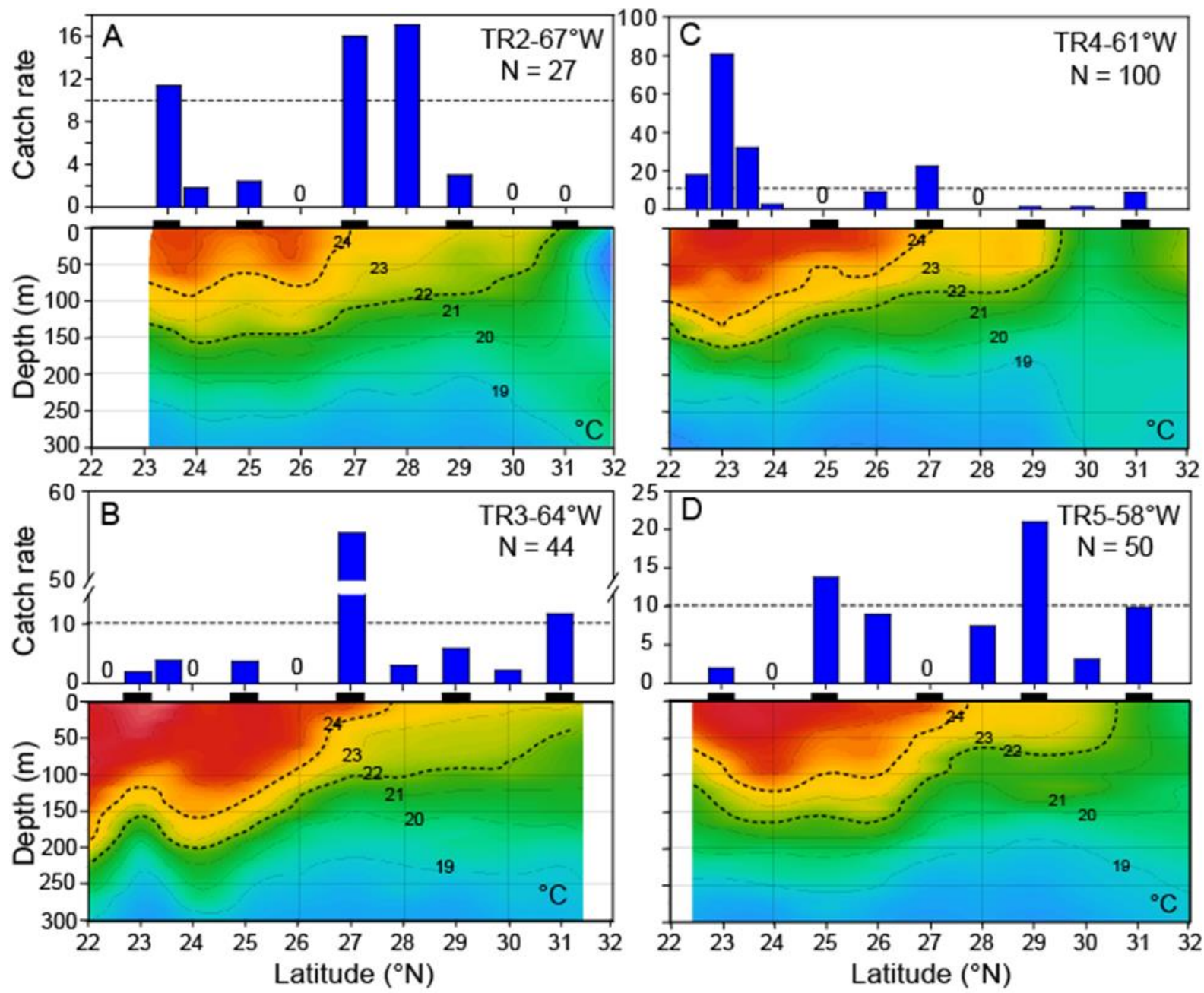

Fig. 9. Individual-station catch rates (number of larvae per $10^{5} \mathrm{~m}^{3}$ of water filtered) of the Ariosoma balearicum leptocephali (including HC and LC forms) collected by the standardized IKMT tows in the 4 eastern transects (TR 2-5) during the 2015 sampling survey plotted over temperature sections in the upper $300 \mathrm{~m}$. The dotted lines show a catch rate of 10 in each plot for easy inter-comparison, and black rectangles below the bars show stations sampled at night. Zeros above the $\mathrm{x}$-axes show stations with no catches in the standard tows.

Collections by other gear types

Some leptocephali collected in the other types of nets used during the $3 \mathrm{WH}$ and $2015 \mathrm{MSM}$ surveys provided useful information. During 2015, 4 A. balearicum $(80-101 \mathrm{~mm}$ ) were among the 30 leptocephali collected by the MOCNESS-1, and none were caught by the Multinet Vertical Plankton Sampler. The only leptocephali collected in 5 of the 33 manta surface net deployments in 2015 were $A$. balearicum $(\mathrm{N}=44,1-31$ per deployment, $77-108 \mathrm{~mm})$. Out of the 37 A. balearicum collected in 8 of the 10 deployments of the $5-\mathrm{mm}$ mesh IKMT, 8 were $>100 \mathrm{~mm}$, resulting in a higher mean TL (101.3 \pm $20.5 \mathrm{~mm})$ than the overall survey means for non-metamorphosing larvae $(87-89 \mathrm{~mm}$, Table 1$)$. The 4 deployments of the large trawl in 2011 captured 45 A. balearicum (most larvae probably passed through the large mesh), with 17 of the larvae being $100-176 \mathrm{~mm}$ and there being a high overall average size of $110.4 \pm 31.6 \mathrm{~mm}$ for trawl-caught larvae. Few were caught in the trawl deployments in other years due to deep fishing.

Genetic differences between larval forms

The 4 non-metamorphosing HC leptocephali used for sequencing were collected by IKMT from a station in the northern part of the $61^{\circ} \mathrm{W}$ transect (no. 939, $91 \mathrm{~mm}, 130 \mathrm{TM}$; no. 940, $100 \mathrm{~mm}, 128 \mathrm{TM}$; no. 941, $88 \mathrm{~mm}, 131 \mathrm{TM}$ ) and farther north in the northern part of the $64^{\circ} \mathrm{W}$ transect (no. 1886, $132 \mathrm{~mm}, 133 \mathrm{TM}$ ). A non-metamorphosing LC leptocephalus (no. 1741, $132 \mathrm{~mm}, 124 \mathrm{TM}$ ) and a metamorphosing larva (no. $1740,148 \mathrm{~mm}, 124 \mathrm{TM}$ ) were also collected in that part of the $64^{\circ} \mathrm{W}$ transect (Fig. 1A). Two other metamorphosing LC larvae that were collected by the large midwater trawl in the westernmost $70^{\circ} \mathrm{W}$ transect (no. 159, $158 \mathrm{~mm}, 124 \mathrm{TM}$; no. 160, $151 \mathrm{~mm}, 122 \mathrm{TM}$ ) were also used. 
The nucleotide sequences of 16S rRNA barcodes were successfully retrieved from all analyzed samples. After trimming, the dataset showed 589 nucleotides, comprising 11 variable sites with 11 parsimony informative sites. The sequences of the $\mathrm{HC}$ and LC larvae were clearly different from all 598 bp of the HC larvae being identical, with 2 of the LC differing from the other two by the same $1 \mathrm{bp}$ (Online Resource 1). The mean genetic distances between the A. balearicum HC and LC leptocephali were $0.018 \pm 0.006$ compared to $0.007 \pm 0.003$ between A. rostrata (American eel) and A. anguilla (European eel). The distances between the 2 types of A. balearicum larvae and the 2 anguillid species ranged from $0.185 \pm 0.019$ to $0.191 \pm 0.020$. The HC and LC larvae differed by either 10 or $11 \mathrm{bp}$. Their percentage genetic distance differences were $1.67 \%$ or $1.84 \%$, compared to $0.7 \%$ divergence between the two anguillid eel species. Therefore, the sequence divergence was greater between the HC and LC larvae than between the two Atlantic anguillid eels.

\section{Discussion}

Distribution and size of leptocephali

The data from the March-April 2011-2017 sampling surveys of this study provided the first detailed view of the distribution of A. balearicum leptocephali across the Subtropical Convergence Zone (STCZ) in both latitudinal and longitudinal axes during both individual years and collectively by combining years. This showed that the larvae of particularly the $\mathrm{HC}$ form of this species were present in single seasons across the STCZ from $70^{\circ} \mathrm{W}$ in the west to $38^{\circ} \mathrm{W}$ in the east (2014), and from $22.5-31^{\circ} \mathrm{N}$ (2015). These larvae were present at various sizes mostly within the $80-100 \mathrm{~mm}$ range across the entire areas sampled in all 4 years. This is a remarkably consistent size range that is essentially identical to the size ranges collected during the 5 previous IKMT surveys (1981-1989) during February-April (Miller 2002). The previous study showed they were also abundant farther west at $74^{\circ} \mathrm{W}$ in 1989 and at $73^{\circ} \mathrm{W}$ in 1983 during February, with the smallest specimens $(52-57 \mathrm{~mm})$ being collected in those transects along with high proportions of larger larvae. The mean sizes in February $1981(84.1 \mathrm{~mm})$ and $1983(83.8 \mathrm{~mm})$ were slightly smaller than the $87-91 \mathrm{~mm}$ mean values from our March-April surveys, but a higher proportion of large larvae were collected in February 1989 farther west at $74^{\circ} \mathrm{W}$ (mean: $94.9 \mathrm{~mm}$ ). This indicates that similar size ranges of leptocephali could have been distributed across the entire STCZ during the February-April season of 8 different years and that there may be more LC larvae in the western areas near the Bahamas. Smith (1989b) also reported similar sizes being collected in the STCZ in March-April 1979. They were also present in the waters near Bermuda in the north in all 4 recent surveys and in April 1993 (Miller 2002). They were present north of, between, and south of the 2 fronts, which was also seen in the long March 1985 transects that crossed the fronts from $25.5-31^{\circ} \mathrm{N}$ at 69 and $71^{\circ} \mathrm{W}$ (Miller and McCleave 1994). The highest catch rates in 2015 were found at the southern end of the transect along $61^{\circ} \mathrm{W}$, so it seems possible that A. balearicum leptocephali may be present throughout the Sargasso Sea during the spring season.

In September-October 1984, they were most abundant across the southern Sargasso Sea in the 50$75 \mathrm{~mm}$ size range, with the smallest larvae of about $25 \mathrm{~mm}$ being in the western region near the Florida Current (Miller and McCleave 2007). Similar sizes were also collected near the Florida Current in August 1993 (Miller 2015), and in an August 1984 survey (McCleave and Kleckner 1987) they were widely distributed across the southwestern Sargasso Sea (Miller and McCleave Unpubl. data). During the summer and fall, LC larvae as small as $10 \mathrm{~mm}$ and $21-30 \mathrm{~mm} \mathrm{HC}$ were collected along the western side of the Florida Current (Ross et al. 2007). Two size classes of LC larvae were abundant during the 1984 survey station in the Providence Channel (Miller 2002; Miller and McCleave 2007). In the STCZ, a lack of data still exists for various months during early summer (May-July) and early winter (December, January), but considering the various size ranges of larvae in other months, it is likely these larvae are present in the Sargasso Sea during most of the year.

The leptocephali of $A$. balearicum were also collected at the surface by the Manta trawl (a neuston net) in 2015, indicating they can be present at a variety of depths from the surface down to $250 \mathrm{~m}$ within the Sargasso Sea (Castonguay and McCleave 1987; Miller 2009; Miller 2015) and even deeper in the Florida Current area (Ross et al. 2007). Ariosoma balearicum leptocephali were also collected in neuston nets along the Florida Current (Ross et al. 2007) and Gulf of Mexico (Quattrini et al. 2019), and other species of Ariosoma have been collected at the surface in the Indo-Pacific (Miller et al. 2006). A variety of different species of leptocephali have been collected at the surface in neuston-type nets mostly at night (Ross et al. 2007; Miller 2009), but why these larvae come up to the surface is not known.

The use of multiple types of gear in the present study indicates that using only one type of sampling gear, even a relatively large IKMT, may not adequately sample some of the larger leptocephali present (e.g., larger than $100 \mathrm{~mm}$ ). Few larvae were collected by small-mouth opening nets (MOCNESS-1, 
Multinet Vertical Plankton Sampler), possibly due to net avoidance and lower volumes of water sampled, but even the IKMT may not adequately catch larger larvae. Any A. balearicum at the surface will also not be caught by normal plankton trawling, at least by gear deployed from the back of the ship. A higher proportion of large larvae was collected in the slightly larger 5-mm mesh IKMT in 2015 that was towed at $3 \mathrm{kn}$ instead of $2 \mathrm{kn}$ for the standard IKMT. The analysis of Miller et al. (2013) suggested that large leptocephali and perhaps even a few types of species may frequently avoid the standard IKMT tows, but they can be caught by the much larger pelagic trawl. For the large trawl however, most leptocephali likely pass through the large mesh, so multiple types of gear seem to be needed to fully evaluate the distribution, size and abundance of leptocephali such as A. balearicum that grows to large sizes.

Larval dispersal of $\mathrm{HC}$ and LC larvae

The fact that the same general size of A. balearicum larvae are apparently present during each year of the February to April season across the STCZ from $74^{\circ} \mathrm{W}$ to $38^{\circ} \mathrm{W}$, a distance of about $3500 \mathrm{~km}$ (including data of Miller 2002), can now be used to evaluate the possible factors influencing the larval dispersal of the two types of larvae. The assemblage of leptocephali in the STCZ is remarkably similar among years as reported previously (Miller and McCleave 1994; Miller 1995; Miller et al. 2013; Ayala et al. 2016). The relative abundance of $A$. balearicum larvae appears to be similar to previous years, even though anguillid larvae are much less abundant in recent years (Hanel et al. 2014; Westerberg et al. 2018). Variations occur in the geographic occurrences of the smallest larvae or proportions of larger mostly LC larvae, but the fact that the primary size range of mostly $\mathrm{HC}$ larvae in the $80-100 \mathrm{~mm}$ range is present across the STCZ region regardless of location suggests that there is a consistent pattern of seasonal spawning and dispersal within the subtropical gyre among years. One implication is that if the source of the offshore larvae was from one direction, such as from west-to-east within eastward frontal jets, the HC larvae should be larger in the east, which was not found. It also seems that if the HC larvae were from spawning somewhere else other than along the east side of the Florida Current, such as the west side of the Florida Current along the $\mathrm{SAB}$ where the juveniles live, it is unlikely that transport from the west to the east side of the Florida current would be so constant that it would produce such a stable pattern of distribution and size of larvae throughout the Sargasso Sea. They would also not be expected to be one of the most abundant types of larvae there. It does seem possible though, that if spawning occurs on the east side of the Florida Current, a combination of transport processes including both the eastward frontal jets and Gulf Stream recirculation from the north could result in the observed patterns of distribution, abundance, and size within all the various surveys that have been conducted in the STCZ.

The previous study also examined catches from the summer and fall in the southern and northern Sargasso Sea and the Florida Current and western Gulf Stream areas and found that the smallest HC larvae of about 18-55 $\mathrm{mm}$ were caught in the Gulf Stream area in September along with larvae up to about $60 \mathrm{~mm}$ (Miller 2002). These samples were collected by the $10^{2} \mathrm{~m}$ mouth-opening MOCNESS-10 or an RMT (a single $10^{2} \mathrm{~m}$ rectangular net), but those nets have 3-mm diameter mesh size, which would not retain the smallest larvae. Even with that limitation, available data including the small larvae in the Florida Current area in October 1984 (Miller and McCleave 2007, Unpubl. data: small HC larvae were collected at St. 1, $33 \mathrm{~mm}$, St. 2, $34 \mathrm{~mm}$, and St. 3, 25, 26, $28 \mathrm{~mm}$ during that survey), suggest that the HC form spawns during the summer along the eastern side of the Florida Current after a spawning migration from the South Atlantic Bight (Miller 2002) where HC eels have been reported to live (Smith 1989a). Although, Ross et al. (2007) reported that 16 small HC larvae (21-30 mm) were collected in the western Florida Current region, possibly in their more frequent August sampling, examinations of sea surface temperature imagery of the Florida Current suggest that water from the western Sargasso Sea can be entrained as filaments of water into the main body of the Florida Current (see imagery in Govoni and Spach 1999, Fig. 1A; McGowan and Richards 1989, Fig. 5, 6, 7; Miller 2015, Fig. 1A, B). These types of intrusions from east to west or warm-core rings influencing the water masses near Cape Hatteras could result in HC larvae sometimes being present on the west side of the Florida Current, where exchange of Gulf Stream water into the coastal water mass has been observed (Govoni and Spach 1999).

A different species, Ariosoma meekii has recently been suggested to spawn in association with the western edge of the Kuroshio Current in the East China Sea (directly analogous to the Florida Current in its position relative to the adjacent subtropical gyre) by collection of gravid adult eels (Watanabe et al. 2016). That type of location on the opposite side of the current compared to A. balearicum is different though, because it would result in larval dispersal to the continental shelf areas inshore of the Kuroshio near Japan and Korea. Another species in that western Pacific region, Ariosoma major, an eel of continental waters along East Asia, likely has a similar spawning location as the HC A. balearicum however, because their larvae have been genetically identified far offshore in the subtropical gyre where 
they are consistently present at large sizes (Ma et al. 2008a; Miller and Tsukamoto Unpubl. data) in what appears to be a directly analogous spawning (east side of the Kuroshio and Florida Current) and larval dispersal strategy for the two species, which will be the subject of a similar future study using data from many different years.

For both A. major and A. balearicum, spawning on the east side of the boundary currents seems to be locations that would result in their larvae being widely dispersed throughout the subtropical gyres. Sea surface temperature images of the Florida Current and western Sargasso Sea (Miller 2015) illustrate the dynamic nature of the region, where the high velocity Florida Current (Leaman et al., 1987; Meinen et al., 2010) can result in frequent eddies and intrusions into the western Sargasso Sea (Vukovich and Crissman 1978; Cornillon et al., 1986) that could mix larvae eastward as well as westward as mentioned above. Gulf Stream cold-core rings could also help to move larvae southward into the Sargasso Sea (Richardson 1980, 1983). These recirculations of the Florida Current in conjunction with recirculation of Gulf Stream water slightly farther downstream along the northern margin of the Sargasso Sea (Fig. 2; McWilliams 1983; Marchese and Gordon 1996; Marchese 1999) would provide a 2-route mechanism that seems to explain the larval distribution of the HC leptocephali in the STCZ. The eddy region along the western Sargasso Sea could feed larvae into the frontal zones that form in fall and are present into late spring (Halliwell and Cornillon 1989, Halliwell et al. 1991, Weller 1991; Ullman et al. 2007). The eastward countercurrents associated with these frontal jets (Eriksen et al. 1991, Weller et al. 1991, Pollard and Regier 1992) could likely take larvae recirculated from the Florida Current eastward into the STCZ, and this could account for the small larvae that were detected in February in the easternmost IKMT sampling conducted in February 1983 and 1989 (Miller 2002) and in 2015. This is illustrated by the positions of the 22 and $24^{\circ} \mathrm{C}$ isotherms in Figure 8, if the frontal currents extend very far into the west. Catch rates were also high in the southern $2 / 3$ of the westernmost 2015 transect and along and between the two fronts, as well as farther south in the $61^{\circ} \mathrm{W}$ transect. The fronts likely move north as the season progresses into the spring and summer (Ullman et al. 2007), so this could leave eastward transported larvae behind at lower latitudes, while others continue being transported eastward.

Recirculation from the north seems likely because the Sargasso Sea has traditionally been considered to be a subtropical gyre in which Gulf Stream water recirculates within a smaller sub-gyre in the north (McWilliams 1983) and through larger-scale basin recirculation as depicted in early circulation plots (Worthington 1976; Wunsch and Grant 1982). A modern representation of this calculated average circulation shown in Figure 2 illustrates how A. balearicum larvae could be transported from the western edge of the gyre to all the places where they have been collected. That circulation map is only a depiction of average water circulation and does not include the frontal jet countercurrent flows that occur at limited spatial and temporal time scales, but some larvae moving directly east through the STCZ would result in an almost completely mixed population of larvae offshore in the central gyre, which is what the present study demonstrates appears to exist.

The smallest LC larvae in the Sargasso Sea region have only been collected within the Northwest Providence Channel of the Northern Bahamas (Miller 2002; Miller and McCleave 2007), but due to various flows through the channel (Richardson and Finlen 1967; Leaman and Molinari 1987) some of these larvae could eventually become dispersed out of that area. In the Gulf of Mexico, Smith (1989b) found that A. balearicum appeared to spawn between August and November, then grow an average of 70 $\mathrm{mm}$ between November and February before starting to metamorphose in April, resulting in a larval duration of about 7-8 months. LC larvae as small as $9 \mathrm{~mm}$ were collected over the continental slope of the northern Gulf of Mexico (Quattrini et al. 2019) and larvae from that region likely contribute larvae to the western Florida Current (Miller 1995). Some LC larvae from the Bahamas could enter the Florida Current and be transported northward and experience similar dispersion routes as the HC larvae. This would explain their widespread presence in low abundances at various latitudes and longitudes in the present study. Others could go east into the northwest flow near Abaco Island (Rosenfeld et al. 1989, Lee et al. 1990; Hacker et al. 1996) (see Fig. 8) or be taken offshore in possible eddy circulations there (Stommel et al. 1978; Gunn and Watts 1982; Olson et al. 1984).

Therefore, the hypothesized presence of these two different spawning locations (HC: eastern edge of the Florida Current; LC: within the Northern Bahamas) in relation to the overall circulation of the region appears to be able to explain the larval distributions of both the HC and LC forms in the Sargasso Sea. There is no way to evaluate if the LC eels of the Bahamas, Gulf of Mexico, and wider Caribbean are all one population/species, but it is possible that they all have a local spawning strategy, with larvae mixing among areas. This is supported by the observation by Ross et al. (2007) that a $10.5 \mathrm{~mm} \mathrm{LC}$ larva was collected off North Carolina, suggesting that LC eels may also be present in the South Atlantic Bight $(\mathrm{SAB})$ and spawn locally unless the larva was rapidly transported into that area by the Florida Current. 
Based on basic ocean current flow patterns, larvae of the HC population off northern South America could also be transported through the Caribbean and into the Florida Current and would be indistinguishable from the large northern HC larvae (Smith 1989b). The northern HC larvae could also be transported through the passages of the Greater Antilles (Johns et al. 2002), so the population structure and larval dispersal of eels and larvae currently considered to be A. balearicum will remain unclear until more research occurs.

\section{Contrasting life histories of 2 cryptic species}

The sequences of mitochondrial 16s DNA analyzed in the present study establishes for the first time that the HC and LC forms of A. balearicum that were initially documented by Smith (1989a,b) are indeed genetically diverged at what appears to be the species level. The HC larvae consistently differed from the LC larvae by either 10 or 11 of the same sequences, and their genetic distances were greater than between the American and European eels. The percentages of genetic distance divergence of the $\mathrm{HC}$ and LC larvae were $1.7-1.8 \%$, which was higher than the divergence of $0.7 \%$ between the American and European eels. The average 16s divergences within species calculated using the same method for many fishes in one region of the Indo-Pacific was $0.27 \%$ and $2.4 \%$ between genera (Zang and Hanner 2012), so the $\mathrm{HC}$ and $\mathrm{LC}$ forms seem to be diverged at the species level.

This is an expected result, because there seem to be few alternate explanations for the observed geographic distribution patterns of both the adults and the larvae with different ranges of vertebrae and myomeres as discussed below. Similar differences in vertebral counts in eels have been found in geographically separated individuals that are likely reflecting different populations within the widespread anguillid species Anguilla marmorata and A. megastoma (Watanabe et al. 2008, 2011) that also show genetic divergences for A. marmorata (Minegishi et al. 2008). Cryptic mitochondrial lineages or cryptic species were found in the widespread Indo-Pacific marine eel species Uroconger lepturus, by analyzing $16 \mathrm{~S}$ rRNA sequences of leptocephali (Ma et al. 2008b), and cryptic species were also found in the chlopsid eel Kaupichthys diodontis in the Indo-Pacific (Hubert et al. 2012). DNA sequence analyses are finding many cases of possible cryptic fish species that are genetically different among regions, which in some cases would be expected to occur for widely distributed species such as for gobiids and other fishes (e.g., Hubert et al. 2012; Hyde et al. 2014; Winterbottom et al. 2014).

Although the presence of cryptic species of A. balearicum may be expected because of the clearly different vertebral or myomere ranges, it is still a remarkable and perhaps somewhat unique situation based on its implications. If the hypothesis about the life history of the northern HC species outlined above is correct, after the eels migrate to spawn on the eastern side of the Florida Current to enable larval development to occur in the Sargasso Sea gyre, the metamorphosing larvae must then swim across the Florida Current to reach the SAB where the HC adults have been found (Smith 1989a). Metamorphosing HC were collected in the Florida Current during both of the August and February MOC-10 surveys in 1978 and 1979, whereas metamorphosing LC larvae were only caught there in the February survey (Miller 2002). It is possible those $\mathrm{HC}$ larvae were in the process of swimming across the current to reach the $\mathrm{SAB}$, but the eventual fate of the LC larvae is unclear, especially since many of those were caught on the western side of the current and were suggested to possibly coming from the Gulf of Mexico. Ross et al. (2007) discussed the possibility that long-lived leptocephali from the WNA seem to reach the eastern Atlantic by Gulf Stream flow and therefore might be able to then follow the larger basin-scale gyre circulation to return back to the western side of the Atlantic. But this might take a long period of time, so most of these larvae might also just be lost from their populations (Ross et al. 2007).

It is not known if the HC leptocephali are adapted to avoid continued eastward transport in the Gulf Stream, but their consistent abundance in the central Sargasso Sea seems to indicate that this area is used for their larval growth stage. If it was not their intended larval development area, and these larvae actually originated from spawning near their apparent juvenile habitats in the SAB and are accidentally transported into the Sargasso Sea, it would be expected that the species assemblages of leptocephali in the eastern SAB and Florida Current would be similar to those in the Sargasso Sea. However, leptocephalus assemblages in the two areas are very different (Miller and McCleave 1994, 2007; Miller 1995; Ross et al. 2007), and there is no consistent evidence of spawning by A. balearicum in the SAB based on ichthyoplankton surveys (Fahay 1975; Powles and Stender 1976; Powell and Robbins 1994, 1998; Marancik et al. 2005; Quattrini et al. 2005). Therefore, there is seemingly no explanation for why the HC larvae are abundant in the Sargasso Sea and other species such as Paraconger and Rhynchoconger, which are abundant in the same areas of the Florida Current, are not (Miller and McCleave 1994; Miller 1995; Ross et al. 2007; Ayala et al. 2016), other than the HC eels spawning somewhere along the eastern FC. For the HC leptocephali that are consistently abundant in the Sargasso Sea, the overall flow-field 
there mainly consists of westward moving mesoscale eddies (Halliwell et al. 1991) that would transport them in the direction of their presumed recruitment area. For them to use the Sargasso Sea gyre as a larval development nursery area, they must also be able to swim across the Florida Current to reach the $\mathrm{SAB}$ for recruitment. Because the HC larvae have never experienced being in the $\mathrm{SAB}$, it would represent a case of genetically programmed larval homing to a specific region of juvenile growth habitat. This is essentially the same as what the American eel leptocephali must do after their larvae eventually spread out to fill the Sargasso Sea gyre (Miller et al. 2015; Miller and Tsukamoto 2017), which indicates this type of larval behavior is possible. The main difference between the $\mathrm{HC}$ eels and American eel larval distribution patterns is that the latter originate from spawning south of the $22^{\circ} \mathrm{C}$ front, and their continental species range is much larger. American eel larvae that may get transported south out of the Sargasso Sea through southerly passages (Johns et al. 2002) could also end up recruiting to areas adjacent to the Caribbean or get transported into the Gulf of Mexico.

However, for the larvae of both species that are retained in the Sargasso Sea, and also those of the American conger eel, Conger oceanicus, that spawns in the southwestern Sargasso Sea (McCleave and Miller 1994; Miller et al. 2011), there does not appear to be any physical mechanism to transport most of their larvae across the Florida Current and Gulf Stream each year even if there are episodic events of westward transport across the current (Miller and Tsukamoto 2017). This seems to make active swimming the only logical mechanism for most larvae to cross the current and reach their recruitment habitats. Swimming behavior has been shown to be required for American eel larvae to successfully recruit by crossing out of the Florida Current in larval transport modelling simulations (Rypina et al. 2014). A recent more detailed transport modelling simulation study of Japanese eel larvae, clearly showed that directional swimming used by larvae during several stages of their larval migration, including crossing out of the Kuroshio, increased recruitment success (Chang et al. 2018). The late-stage larvae of A. balearicum reach larger maximum sizes (mostly < $200 \mathrm{~mm}$; Smith 1989b) compared to American and Japanese eel larvae $(\sim 70 \mathrm{~mm})$, so they would likely be even faster swimmers than anguillid larvae, or the glass eels and American conger eel larvae $(<120 \mathrm{~mm})$ that have been studied for their swimming abilities (Wuenschel and Able 2008). Even much smaller coral reef fish larvae have been found to have remarkable sustained swimming abilities (Fisher and Wilson 2004), and the role of active swimming by fish larvae has been increasingly discussed (Leis 2002, 2006).

Alternative explanations for the predominance and abundance of HC leptocephali in the Sargasso Sea and the proposed life history strategy seem to be difficult to formulate considering the geography of currents and juvenile/adult habitats of this species and the lack of evidence of spawning in the SAB region. An important aspect of the scenario is based on the geographic distribution of the HC and LC eel vertebral counts of Smith (1989a). These vertebral counts included at least a few eel specimens from many coastal areas of the WNA including the Bahamas $(\mathrm{N}=22)$, Biscayne Bay Florida, Florida Keys, Bermuda, the Gulf of Mexico, and the western Caribbean $(\mathrm{N}=2-6)$, which were all in the LC range. However, all specimens from north of Palm Beach Florida $(\mathrm{N}=27)$ along the SAB had HC vertebral counts. The number of samples and their geographic distribution is obviously insufficient to provide a clear understanding of the zoogeography and life histories of the minimum of three apparent cryptic species A. balearicum in the WNA (including the southern HC population). The fact that Smith (1989a) found only $\mathrm{HC}$ eels from about 6 different SAB locations, and the predominance of HC leptocephali in the Sargasso Sea gyre and among the metamorphosing larvae in the Florida Current about 1 year after the likely summer spawning season, is suggestive that the proposed life history of this HC cryptic species may be possible.

This does not appear to be the only example of an eel species/cryptic species that seems to recruit to a specific geographic area, when the ocean currents should transport their larvae to many other areas. Both Anguilla bornenesis and A. luzonesis are only known to be present in significant numbers in eastern Borneo and the Philippines, respectively, despite there being a lack of specific currents that would only take them there from offshore spawning and not to other places (Aoyama et al. 2003; Kuroki et al. 2012; Han et al. 2016). If the abundant Sargasso Sea HC leptocephali of A. balearicum do actually move west and swim across the powerful Florida Current, it will represent a remarkable example of active larval swimming to a particular area, because there is no physical mechanism to transport them across such a powerful current. Active larval behavior to reach recruitment areas in relation to population connectivity and self-recruitment, and even larval homing, are increasingly being evaluated for coral reef fishes (Gould and Dunlap 2017 and references therein), but these are typically cases of larvae that were hatched near the habitats that they attempt to return to over much smaller scales. What is interesting about the HC $A$. balearicum scenario being discussed here and also for anguillids and conger eels, is that their larvae are returning to habitats they have never experienced after being hatched offshore in different water masses 
and being dispersed over thousands of kilometers. Genetically programmed migration behaviors have been proposed to be used by other long-distance migrating marine species such as sea turtles and salmon based on cues from the earth's geomagnetic field (Lohmann et al. 2001; Putman et al. 2014, 2015). Anguillid eels possess this sense and can likely use it for orientation, but it is a difficult challenge to determine if leptocephali can use geomagnetic cues to facilitate their long migrations to specific areas (e.g., Cresci et al. 2017; Durif et al. 2017).

Future collections of larvae and adults that are analyzed using both vertebral and myomere counts along with DNA sequence analyses are needed to determine if this remarkable larval migration actually occurs and what populations, cryptic species or subspecies exist in the WNA. While the spawning location of $\mathrm{HC}$ eels remains to be determined, it appears possible that A. balearicum may represent an interesting example of how natural selection has influenced the spawning location and larval dispersal and recruitment behaviors of species in relation to the geography of growth habitats and strong ocean currents. The leptocephalus body form, which accumulates energy storage compounds that could be used for late-stage larval swimming may be an important reason this is possible (Miller and Tsukamoto 2017). These factors also seem to raise the question about how many other eel species, or even local cryptic species, may exist that have evolved complex larval migration behaviors to enhance self-recruitment to specific areas that are difficult to reach using passive larval drifting alone.

\section{Acknowledgements}

We thank the captains and crews of the R/V Walther Herwig III and the R/V Maria S. Merian of Germany for their assistance in deploying the sampling gear, and the technicians and other scientists from several different countries for their assistance to sort the leptocephali out of the plankton samples. We also acknowledge the importance of the Sargasso Seas sampling surveys of J. D. McCleave and of the larval and adult meristic data obtained by D. G. Smith in building an information base about this species in the WNA. Funding for the cruises was provided by the German Federal Ministry of Food and Agriculture $(2011,2014,2017)$ and by the Senate Commission on Oceanography of the German Research Foundation (DFG) (2015).

\section{References}

Aoyama J, Wouthuyzen S, Miller MJ, Inagaki T, Tsukamoto K (2003) Short-distance spawning migration of tropical freshwater eels. Biol Bull 204:104-108

Anibaldi A, Franciosi CB, Massari F, Tinti F, Piccinetti C, Giccion G (2016) Morphology and species composition of southern Adriatic Sea leptocephali evaluated using DNA barcoding. PLoS One 11:e0166137

Ayala A, Riemann L, Munk P (2016) Species composition and diversity of fish larvae in the Subtropical Convergence Zone of the Sargasso Sea from morphology and DNA barcoding. Fish Oceanogr 23:85-104

Böhlke E, Editor (1989) Leptocephali. Fishes of the Western North Atlantic. Mem Sears Found Mar Res 1(9):657-1055

Bonjean F, Lagerloef GSE (2002) Diagnostic model and analysis of the surface currents in the tropical Pacific Ocean. J Phys Oceanogr 32:2938-2954

Caldeira RMA, Reis JC (2017) The Azores Confluence Zone. Front Mar Sci 4:37

Castonguay M, McCleave JD (1987) Vertical distributions, diel and ontogenetic vertical migrations and net avoidance of leptocephali of Anguilla and other common species in the Sargasso Sea. J Plankt Res 9:195-214

Chang Y-L, Miller MJ, Tsukamoto K, Miyazawa Y (2018) Effect of larval swimming in the western North Pacific subtropical gyre on the recruitment success of the Japanese eel. PlosOne 13(12): 0208704

Cornillon P, Evans D, Large W (1986) Warm outbreaks of the Gulf Stream into the Sargasso Sea. J Geophys Res 91:6583-6596

Crabtree RE, Cyr EC, Bishop RE, Falkenstein LM, Dean JM (1992) Age and growth of tarpon, Megalops atlanticus, larvae in the eastern Gulf of Mexico, with notes on relative abundance and probable spawning areas. Environ Biol Fish 35:361-370

Cresci A, Paris CB, Durif CMF, Shema S, Bjelland RM, Skiftesvik AB, Browman HI (2017) Glass eels (Anguilla anguilla) have a magnetic compass linked to the tidal cycle. Sci Adv 3:e1602007

Durif C, Honhommeau S, Briand C, Browman HI, Castonguay M, Daverat F, and others (2017) Whether European eel leptocephali use the Earth's magnetic field to guide their migration remains an open 
question - Comment on "A Magnetic Map Leads Juvenile European Eels to the Gulf Stream", by Naisbett-Jones et al. (2017). Cur Biol 27:R979-R1001

Eriksen CC, Weller RA, Rudnick DL, Pollard RT, Regier LA (1991) Ocean frontal variability in the Frontal Air-Sea Interaction Experiment. J Geophys Res 96:8569-8591

Fahay MP (1975) An annotated list of larval and juvenile fishes captured with surface-towed meter net in the South Atlantic Bight during four RV Dolphin cruises between May 1967 and February 1968. NMFS Tech Rep SSRF 685

Fahay MP (2007) Early stages of fishes in the western North Atlantic Ocean: Davis Strait, Southern Greenland and Flemish Cap to Cape Hatteras. Vol. 1 Acipenseriformes through Syngnathiformes. Northwest Atlantic Fisheries Organization, Dartmouth (http://www.nafo.int/publications/fahay/pdfs.html)

Fahay MP, Obenchain CL (1978) Leptocephali of the ophichthid genera Ahlia, Myrophis, Ophichthus, Pisodonophis, Callechelys, Letharchus, and Apterichtus on the Atlantic continental shelf of the United States. Bull Mar Sci 28:442-486

Fisher R, Wilson SK (2004) Maximum sustainable swimming speeds of late-stage larvae of nine species of reef fishes. J Exper Mar Biol Ecol 312:171-86

Gould AL, Dunlap PV (2017) Genomic analysis of a cardinalfish with larval homing potential reveals genetic admixture in the Okinawa Islands. Molec Ecol 26:3870-3882

Govoni JG, Spach HL (1999) Exchange and flux of larval fishes across the western Gulf Stream front south of Cape Hatteras, USA, in winter. Fish Oceanogr 8(Supl. 2):77-92

Gunn JT, Watts, DR (1982) On the currents and water masses north of the Antilles/Bahamas Arc. J Mar Res 40:1-18

Hacker P, Firing E, Wilson, WD, Molinari R (1996) Direct observations of the current structure east of the Bahamas. Geophys Res Lett 23:1127-1130

Halliwell GR Jr, Cornillon P (1989) Large-scale SST anomalies associated with subtropical fronts in the western North Atlantic during FASINEX. J Mar Res 47:757-775

Halliwell GR Jr, Ro, YJ, Cornillon P (1991) Westward-propagating SST anomalies and baroclinic eddies in the Sargasso Sea. J Phys Oceanogr 21:1664-1680

Han Y-S, Lin Y-F, Wu C-R, lizuka Y, Castillo TR, Yambot IU, Mamalangkap MD, Yambot AV (2016) Biogeographic distribution of the eel Anguilla luzonensis: dependence upon larval duration and oceanic currents. Mar Ecol Prog Ser 551:227-238

Hanel R, Stepputtis D, Bonhommeau S, Castonguay M, Schaber M, Wysujack K, Vobach M, Miller MJ (2014) Low larval abundance in the Sargasso Sea: new evidence about reduced recruitment of the Atlantic eels. Naturwissenschaften 101:1041-1052

Hubert N, Meyer CP, Bruggemann HJ, Guérin F, Komeno RJL, Espiau B, et al. (2012) Cryptic diversity in Indo-Pacific coral-reef fishes revealed by DNA-barcoding provides new support to the centre-ofoverlap hypothesis. PLoS ONE 7(3):e28987

Hyde JR, Underkoffler KE, Sundberge MA (2014) DNA barcoding provides support for a cryptic species complex within the globally distributed and fishery important opah (Lampris guttatus). Molec Ecol Resources 14:1239-1247

Johns WE, Townsend TL, Fratantoni DM, Wilson WD (2002) On the Atlantic inflow to the Caribbean Sea. Deep-Sea Res 49:211-243

Johnson ES, Bonjean F, Lagerloef GSE, Gunn JT, Mitchum GT (2007) Validation and error analysis of OSCAR sea surface currents. J Atmosph Oceanic Technol 24:688-701

Kleckner RC, McCleave JD (1985) Spatial and temporal distribution of American eel larvae in relation to North Atlantic Ocean current systems. Dana 4:67-92

Kleckner RC, McCleave JD (1988) The northern limit of spawning by Atlantic eels (Anguilla spp.) in the Sargasso Sea in relation to thermal fronts and surface water masses. J Mar Res 46:647-667

Kimura M (1980) A simple method for estimating evolutionary rate of base substitutions through comparative studies of nucleotide sequences. J Molec Evol 16:111-120

Kumar S, Stecher G, Li M, Knyaz C, Tamura K (2018) MEGA X: Molecular Evolutionary Genetics Analysis across computing platforms. Molec Biol Evol 35:1547-1549

Kuroki M, Aoyama J, Miller MJ, Yoshinaga T, Watanabe S, Tsukamoto K (2012) Offshore spawning of the newly discovered anguillid species Anguilla luzonensis (Teleostei: Anguillidae) in the western North Pacific. Pac Sci 66:497-507

Leaman KD, Molinari RL, Vertes PS (1987) Structure and variability of the Florida Current at $27^{\circ} \mathrm{N}$ : April 1982-July 1984. J Phys Oceanogr 17:566-583 
Leaman KD, Molinari RL (1987) Topographic modification of the Florida Current by Little Bahama and Great Bahama Banks. J Phys Oceanogr 17:1724-1736

Lee TN, Johns W, Schott F, Zantopp R (1990) Western boundary current structure and variability east of Abaco, Bahamas at $26.5^{\circ}$ N. J Phys Oceanogr 20:446-466

Leis JM (2002) Pacific coral-reef fishes: the implications of behaviour and ecology of larvae for biodiversity and conservation, and a reassessment of the open population paradigm. Environ Biol Fish 65: 199-208

Leis JM (2006) Are larvae of demersal fishes plankton or nekton? Adv Mar Biol 51:57-141

Lischka A, Piatkowski U, Hanel R (2017) Cephalopods of the Sargasso Sea: distribution patterns in relation to oceanography. Mar Biodiv 47:685-697

Lohmann KJ, Cain SD, Dodge SA, Lohmann CMF (2001) Regional magnetic fields as navigational markers for sea turtles. Science 294:364-366

Ma T, Miller MJ, Aoyama J, Minagawa G, Inoue JG, Watanabe S, Tsukamoto K (2008a) Genetic identification of two species of Ariosoma leptocephali. Coast Mar Sci 32:48-53

Ma T, Aoyama J, Miller MJ, Minegishi Y, Inoue JG, Tsukamoto K (2008b) Genetic differentiation in the genus Uroconger in the Indo-Pacific region. Aquatic Biol 2:29-35

Marancik KE, Clough LM, Hare JA (2005) Cross-shelf and seasonal variation in larval fish assemblages on the southeast United States continental shelf off the coast of Georgia. Fishery Bull 103:108-129

Marchese PJ (1999) Variability in the Gulf Stream recirculation gyre. J Geophys Res 104:29,549-29,560

Marchese PJ, Gordon AL (1996) The eastern boundary of the Gulf Stream recirculation. J Mar Res 54:521-540

McCleave JD, Kleckner RC (1987) Distribution of leptocephali of the catadromous Anguilla species in the western Sargasso Sea in relation to water circulation and migration. Bull Mar Sci 41:789-806

McCleave JD, Miller MJ (1994) Spawning of Conger oceanicus and Conger triporiceps (Congridae) in the Sargasso Sea and subsequent distribution of leptocephali. Env Biol Fish 39:339-355

McGowan MF, Richards WJ (1989) Bluefin tuna, Thunnus thynnus, larvae in the Gulf Stream off the southeastern United States: satellite and shipboard observations of their environment. Fish Bull 87:615-631

McWilliams JC (1983) On the mean dynamical balances of the Gulf Stream Recirculation Zone. J Mar Res 41:427-460

Meinen CS, Baringer MO, Garcia RF (2010) Florida Current transport variability: an analysis of annual and longer period signals. Deep-Sea Res I 57:835-846

Miller MJ (1995) Species assemblages of leptocephali in the Sargasso Sea and Florida Current. Mar Ecol Progr Ser 121:11-26

Miller MJ (2002) Distribution and ecology of Ariosoma balearicum (Congridae) leptocephali in the western North Atlantic. Env Biol Fish 63:235-252

Miller MJ (2009) Ecology of anguilliform leptocephali: remarkable transparent fish larvae of the ocean surface layer. Aqua-BioSci Monogr 2:1-94

Miller MJ (2015) Nighttime vertical distribution and regional species composition of eel larvae in the western Sargasso Sea. Reg Stud Mar Sci 1:34-46

Miller MJ, McCleave JD (1994) Species assemblages of leptocephali in the Subtropical Convergence Zone of the Sargasso Sea. J Mar Res 52:743-772

Miller MJ, JD McCleave (2007) Species assemblages of leptocephali in the southwestern Sargasso Sea. Mar Ecol Progr Ser 344:197-212

Miller MJ, Tsukamoto K (2017) The ecology of oceanic dispersal and survival of anguillid leptocephali. Can J Fish Aquat Sci 74:958-971

Miller MJ, Wouthuyzen S, Minagawa G, Aoyama J, Tsukamoto K (2006) Distribution and ecology of leptocephali of the congrid eel, Ariosoma scheelei, around Sulawesi Island, Indonesia. Mar Biol 148:1101-1111

Miller MJ, Yoshinaga T, Aoyama J, Otake T, Mochioka N, Kurogi H, Tsukamoto K (2011) Offshore spawning of Conger myriaster in the western North Pacific: evidence of convergent migration strategies of anguilliform eels in the Atlantic and Pacific. Naturwissenshaften 98:537-543

Miller MJ, Stepputtis D, Bonhommeau S, Castonguay M, Schaber M, Vobach M, Hanel R (2013) Comparisons of catches of large leptocephali using an IKMT and a large pelagic trawl in the Sargasso Sea. Mar Biodivers 43:493-501

Miller MJ, Bonhommeau S, Munk P, Castonguay M, Hanel R, McCleave JD (2015) A century of research on the larval distributions of the Atlantic eels: a reexamination of the data. Biol Rev 90:1035-1064 
Miller, MJ, Westerberg H, Sparholt H, Wysujack K, Sørensen SR, Marohn L et al. 2019. Spawning by the European eel across $2000 \mathrm{~km}$ of the Sargasso Sea. Biol Lett 15, 20180835

Minegishi Y, Aoyama J, Tsukamoto K (2008) Multiple population structure of the giant mottled eel Anguilla marmorata. Mol Ecol 17:3109-3122

Munk P, Hansen MM, Maes GE, Nielsen TG, and others (2010) Oceanic fronts in the Sargasso Sea control the early life and drift of Atlantic eels. Proc Roy Soc B 277:3593-3599

Olson DB, Schott FA, Zantopp RJ, Leaman KD (1984) The mean circulation east of the Bahamas as determined from a recent measurement program and historical XBT data. J Phys Oceanogr 14:1470 1487

Onda H, Miller MJ, Takeshige A, Miyake Y, Kuroki M, Aoyama J, Kimura S (2017) Vertical distribution and assemblage structure of leptocephali in the North Equatorial Current region of the western Pacific. Mar Ecol Prog Ser 575:119-136

Pollard RT, Regier LA (1992) Vorticity and vertical circulation at an ocean front. J. Phys. Oceanogr. 22: 609-625

Powell AB, Robbins RE (1994) Abundance and distribution of ichthyoplankton along an inshoreoffshore transect in Onslow Bay, North Carolina. NOAA Tech Rep NMFS 120

Powell AB, Robbins RE (1998) Ichthyoplankton adjacent to live-bottom habitats in Onslow Bay, North Carolina. NOAA Tech Rep NMFS 133

Powles H, Stender W (1976) Observations on composition, seasonality and distribution of ichthyoplankton from MARMAP cruises in the South Atlantic Bight in 1973. Tech Rep SC Mar Resour Cent no. 11, Charleston

Putman NF, Scanlan MM, Billman EJ, O'Neil JP and others (2014) An inherited magnetic map guides ocean navigation in juvenile Pacific salmon. Cur Biol 24:446-450

Putman NF, P Verley, CS Endres, KJ Lohmann (2015) Magnetic navigation behavior and the oceanic ecology of young loggerhead sea turtles. J Exp Biol 218:1044-1050

Quattrini AM, Lindquist DG, Bingham FM, Lankford TE, Govoni JJ (2005) Distribution of larval fishes among water masses in Onslow Bay, North Carolina: implications for cross-shelf exchange. Fish Oceanogr 14:413-431

Quattrini AM, McClain-Counts J, Artabane SJ, Roa-Varon A, McIver TC, Rhode M, Ross SW (2019) Assemblage structure, vertical distributions, and stable isotopic compositions of anguilliform leptocephali in the Gulf of Mexico. J Fish Biol

Richardson PL (1980) Gulf Stream ring trajectories. J Phys Oceanogr 10:90-104

Richardson PL (1983) Gulf Stream rings. pp 19-65. In: A.R. Robinson (ed) Eddies in marine science. Springer-Verlag, New York

Richardson WS, Finlen JR (1967) The transport of Northwest Providence Channel. Deep Sea Res 14:361-367

Rosenfeld LK, Molinari RL, Leaman KD (1989) Observed and modeled annual cycle of transport in the Straits of Florida and east of Abaco Island, the Bahamas (26.5 N). J Geophys Res 94:4867-4878

Ross SW, Casazza TL, Quattrini AM, Sulak KJ (2007) Anguilliform larvae collected off North Carolina. Mar Biol 150:681-695

Rypina II, Llopiz JK, Pratt LJ, Susan Lozier M (2014) Dispersal pathways of American eel larvae from the Sargasso Sea. Limnol Oceanogr 59:1704-14

Schoth M, Tesch F-W (1982) Spatial distribution of 0-group eel larvae (Anguilla sp.) caught in the Sargasso Sea in 1979. Helgolander Meeresunters 35:309-320

Smith DG (1989a) Family Congridae. In: Böhlke EB (ed) Fishes of Western North Atlantic, Part 9, vol 1. Mem Sears Fdn Mar Res, New Haven, pp 460-567

Smith DG (1989b) Family Congridae: Leptocephali. In: Böhlke EB (ed) Fishes of Western North Atlantic, Part 9, vol 2. Mem Sears Fdn Mar Res, New Haven, pp 723-763

Stommel H, Niiler P, Anati D (1978) Dynamic topography and recirculation of the North Atlantic. J Mar Res 36:449-468

Ullman DS, Cornillon PC, Shan Z (2007) On the characteristics of subtropical fronts in the North Atlantic. J Geophys Res C01010

Vukovich FM, Crissman BW (1978) Observations of the intrusion of a narrow warm tongue into the Sargasso Sea using satellite and in situ data. J Geophys Res 83:1929-1934

Watanabe S, Aoyama J, Miller MJ, Ishikawa S, Feunteun E, Tsukamoto K (2008) Evidence of population structure in the giant mottled eel, Anguilla marmorata, using total number of vertebrae. Copeia 2008(3):680-688 
Watanabe S, Miller MJ, Aoyama J, Tsukamoto K (2011) Analysis of vertebral counts of the tropical anguillids, Anguilla megastoma, A. obscura, and A. reinhardtii, in the western South Pacific in relation to their possible population structure. Environ Biol Fish 91:353-360

Watanabe S, Hagihara S, Miller MJ, Machida M, Komatsu K, Nishida S, Tsukamoto K (2016) Collection of spawning-condition eels of Ariosoma meeki in the Kuroshio Current in the East China Sea. J Mar Biol Assoc UK 96:1701-1707

Weller RA (1991) Overview of the frontal air-sea interaction experiment (FASINEX): A study of air-sea interaction in a region of strong oceanic gradients. J Geophys Res 96:8501-8516

Wuenschel MJ, Able KW (2008) Swimming ability of eels (Anguilla rostrata, Conger oceanicus) at estuarine ingress: contrasting patterns of cross-shelf transport? Mar Biol 154:775-786

Westerberg H, Miller MJ, Wysujack K, Marohn L, Freese M, Pohlmann J-D, Watanabe S, Tsukamoto K, Hanel R (2018) Larval abundance across the European eel spawning area: An analysis of recent and historic data. Fish Fisheries 19:890-902

Wiebe PH, Morton AW, Bradley AM, Backus RH, Craddock JE, Barber V, Cowles TJ, Flierl GR (1985) New developments in the MOCNESS, an apparatus for sampling zooplankton and micronekton. Mar Biol 87:313-323

Winterbottom R, Hanner RH, Burridge M, Zur M (2014) A cornucopia of cryptic species - a DNA barcode analysis of the gobiid fish genus Trimma (Percomorpha, Gobiiformes). ZooKeys 381:79111

Worthington LV (1976) On the North Atlantic circulation. The Johns Hopkins Oceanographic Studies No. 6. Johns Hopkins University Press, Baltimore. $110 \mathrm{pp}$

Wuenschel MJ, Able KW (2008) Swimming ability of eels (Anguilla rostrata, Conger oceanicus) at estuarine ingress: contrasting patterns of cross-shelf transport? Mar Biol 154:775-786

Wunsch C, Grant G (1982) Towards the general circulation of the North Atlantic Ocean. Progr Oceanogr $1: 1-59$

Zhang J, Hanner R (2012) Molecular approach to the identification of fish in the South China Sea. PLoS ONE 7:e30621 


\section{Supplementary Material \\ Environmental Biology of Fishes}

\section{Larval Size-Distributions of Ariosoma balearicum Cryptic Species during the March-April Season in the Sargasso Sea Subtropical Convergence Zone}

Michael J. Miller, Lasse Marohn, Klaus Wysujack, Sylvain Bonhommeau, Mari Kuroki, Marko Freese, Jan-Dag Pohlmann, Shun Watanabe, Martin Castonguay, Håkan Westerberg,

Katsumi Tsukamoto, and Reinhold Hanel

Address for correspondence: michael.miller@marine.fs.a.u-tokyo.ac.jp

Online Resource 1. Aligned DNA sequences of 598 base pairs of the mitochondrial 16s rRNA gene of 4 specimens of each of the 2 apparent cryptic species of Ariosoma balearicum leptocephali that are present in the Sargasso Sea of the western North Atlantic, which were collected during the WH342 survey in 2011 (shown by specimen numbers). Different base pairs of the low myomere count form (LC) compared to the high myomere count form (HC) are indicated. The collection locations of LC specimen numbers 159 (158 mm), 160 (151 mm), 1740 (148 mm), 1741 (132 mm), and HC specimen numbers $939(91 \mathrm{~mm}), 940(100 \mathrm{~mm}), 941(88 \mathrm{~mm})$, and $1886(132 \mathrm{~mm})$, are shown in Figure 1 of the paper.

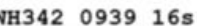
พH $342-0940^{-} 16 \mathrm{~s}$ พH342-0941-16s WH342_1886-16s พH342-0159-16s พH342-0160-16s พH $342^{-} 1740^{-} 16 \mathrm{~s}$ พH342-1741_16s

H342 $093916 \mathrm{~s}$ พH342_0940-16s ผH342_0941-16s WH342-1886-16s NH342-0159-16s พH $342^{-} 0160^{-} 16 \mathrm{~s}$ พH $342^{-} 1740^{-} 16 \mathrm{~s}$ WH342-1741-16s

CGCCTCTAGCCAACAAACATGTATTAGAGGTCCCGCTGCCCAGTGACGATTAGTTCAACGGCCGCAGTATAATGACTGCGCTAAGGTAGCGTAATCAC

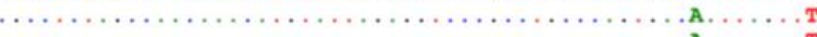

……

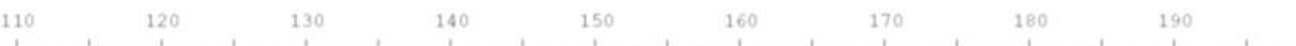

TGCCTTTTAAATAAAGACCAGTATGAATGGCATAACGAGGATTTAACTGTCTCCTTAACCTAGTCAATGAAATTAATCTATCCGTGCAGAAGCGGATA?

AGTACATAAGACGAGAAGACCCTATGGAGCTTTAGGATACGGGGCAAGCATATCAAGAATCATAAAAACAGAACATATTTAAACCTATGTAATATGACC

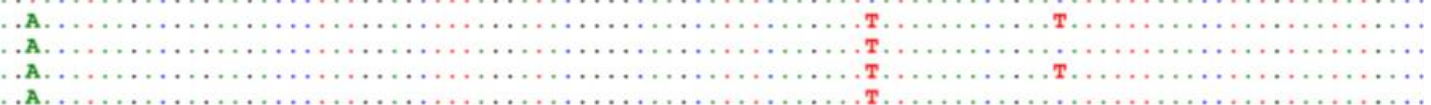

$310 \quad 320 \quad 330 \quad 340$

CCTTCCTTAGGTTGGGGGACCCTGAGGCAAAATATAGCCCTCATATGGAAATATAAAAGATAAACTCTAATTTAGTCTTTTAAACCAAGAGTGACAAC

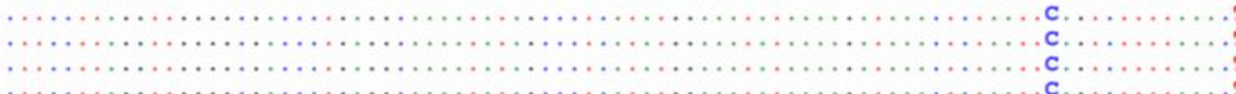

CTAAGAAATAGAACATCTAACCAAAAATGACCCAGGATAAATAAACCTGACAACTGGACCAAGTTACCCTAGGGATAACAGCGCAATCTTCTCTTAGAC … CCCTATCGACGAGAAGGTTACGACCTCGATGTTGGATCAGGACATCCTAATGGTGCAGCCGCTATTAAGGGTCGTTTGTTCAACGATTAAAGTCCT 